\title{
Knowledge and information needs of informal caregivers in palliative care: a qualitative systematic review
}

\begin{abstract}
A Docherty Worcestershire PCT, A Owens Department of Geography, Queen Mary, University of London, London, M Asadi-Lari Warwick Medical School, University of Warwick, Coventry, R Petchey Department of Health Management \& Food Policy, City University, Northampton Square, London, J Williams and Y Carter Warwick Medical School, University of Warwick, Coventry
\end{abstract}

\begin{abstract}
Objectives: To review current understanding of the knowledge and information needs of informal caregivers in palliative settings. Data sources: Seven electronic databases were searched for the period January 1994-November 2006: Medline, CINAHL, PsychINFO, Embase, Ovid, Zetoc and Pubmed using a meta-search engine (Metalib®). Key journals and reference lists of selected papers were hand searched. Review methods: Included studies were peer-reviewed journal articles presenting original research. Given a variety of approaches to palliative care research, a validated systematic review methodology for assessing disparate evidence was used in order to assign scores to different aspects of each study (introduction and aims, method and data, sampling, data analysis, ethics and bias, findings/results, transferability/generalizability, implications and usefulness). Analysis was assisted by abstraction of key details of study into a table. Results: Thirty-four studies were included from eight different countries. The evidence was strongest in relation to pain management, where inadequacies in caregiver knowledge and the importance of education were emphasized. The significance of effective communication and information sharing between patient, caregiver and service provider was also emphasized. The evidence for other caregiver knowledge and information needs, for example in relation to welfare and social support was weaker. There was limited literature on non-cancer conditions and the care-giving information needs of black and minority ethnic populations. Overall, the evidence base was predominantly descriptive and dominated by small-scale studies, limiting generalizability. Conclusions: As palliative care shifts into patients' homes, a more rigorously researched evidence base devoted to understanding caregivers knowledge and information needs is required. Research design needs to move beyond the current focus on dyads to incorporate the complex, three-way interactions between patients, service providers and caregivers in end-of-life care settings. Palliative Medicine (2008); xxx: $1-19$
\end{abstract}

Key words: caregivers; caregiver needs; knowledge and information needs; research design

\section{Introduction}

Given the choice, most people say that they would prefer to die at home. Research conducted for Marie Curie Cancer Care suggested that the proportion of individuals in the UK who would like to die at home was $64 \%$ $(n=2000),{ }^{1}$ while a recent survey for the BMJ suggested a figure of $74 \%(n=1511){ }^{2}$ These findings largely confirm earlier research: a systematic review of studies of preferred place of death established that well over $50 \%$ of patients wanted a home death. ${ }^{3}$ However, the actual place of death of cancer patients and those with other ter-

Correspondence to: Alastair Owens, Senior Lecturer, Department of Geography, Queen Mary, University of London, Mile End Road, London E1 4NS, UK. Email: a.j.owens@qmul.ac.uk minal conditions in the UK does not currently correspond to patient preference. In 2000 , only $23 \%$ of cancer deaths in the UK took place in the patient's own home compared with $55.5 \%$ in hospitals, $16.5 \%$ in hospices and $5 \%$ in other locations. ${ }^{4}$

Developing palliative care services to enable a greater number of people to die at home has become a key policy goal in the UK. The report of the recent Government Select Committee on palliative care in England and Wales argued that home-based care should be promoted, as it offers terminally ill patients greater choice and potentially improves their quality of life. ${ }^{5}$ Indeed, a recent metaevaluation of the effectiveness of palliative care teams suggested evidence of benefit was greatest for patients receiving home care. ${ }^{6}$ There is also an economic argument in favour of moving end of life care into the home: research 
suggests that the costs of providing such care may be half that currently spent on hospital services for the dying. ${ }^{7}$

Moving palliative care into patients' homes raises some important challenges for service providers. Prominent among these is the need for service providers to work effectively with informal caregivers. Informal caregivers (especially close family relatives) frequently play a crucial role in the provision of palliative care. Gomes and Higginson's recent systematic review has demonstrated that the provision of extended family support is an important factor in determining whether a terminally ill patient dies at home. ${ }^{8}$ Understanding caregivers' needs, their varied experiences and the complex interactions between caregivers, health care professionals and patients is important if effective end of life care is to be provided. Published reviews have examined a range of topics in relation to these themes, including which service interventions are most effective in helping caregivers in a range of different settings. ${ }^{9-11}$ However, there has been no recent systematic review of the disparate evidence base covering the knowledge and information needs of caregivers in end of life situations. With the development of home-based palliative care services, it is important that caregivers understand the nature of a patient's illness, the range and scope of service provision and their own role and competencies in palliation. This systematic review assesses the research literature on these knowledge-related needs of caregivers.

\section{Method}

The following databases were searched for the period January 1994-November 2006: Medline, CINAHL, PsychINFO, Embase, Ovid, Zetoc and Pubmed, using a meta-search engine (Metalib®). This period was selected as it allows coverage of the time period in which electronic journal publishing became more widespread in addition to allowing a focus upon recent practice developments with regards to carers, which have developed in particular over the last decade. Keywords included: carer, caregiver, palliative, terminal, end of life and related phrases. This approach was supplemented by hand searching of leading journals (Palliative Medicine, Journal of Palliative Care and International Journal of Palliative Nursing) and systematic checking of the reference lists of all identified papers. Included papers were peer-reviewed English language, journal articles within the search period. Review papers, commentaries, editorials, letters, books, reports and theses were excluded from the study.

Abstracts of papers meeting these inclusion criteria were obtained and independently reviewed by two members of the review team. Because of the volume and variety of papers identified, a subset of articles dealing with issues relating to caregiver knowledge and information needs were selected for inclusion in this review. Full papers were subsequently obtained and independently reviewed by at least two researchers from a dedicated team of four (AD, AO, MAL, RP). Details were entered into a table summarizing the focus, design, main outcomes, weaknesses and generalizability of each study.

The inherent variability in research design (including both qualitative and quantitative studies) and outcome measures characteristic of palliative care research, rendered the use of conventional systematic review methods - principally designed for the evaluation of randomized control trial (RCT) studies - inappropriate. The review was therefore undertaken using a published, validated scoring system for systematically appraising more disparate evidence, including qualitative studies. ${ }^{12}$ This methodology assesses eight study components: introduction and aims, method and data, sampling, data analysis, ethics and bias, results, transferability and generalizability, and implications for policy and practice. Each component is given a score ranging from 1 to 4 (good $=4$, fair $=3$, poor $=2$ or very poor $=1$ ), generating a potential maximum total of 32 .

During the review process, the papers were independently scored by two researchers and where agreement could not be achieved, consensus was obtained via reference to a third team member. Seventeen papers were subsequently excluded, as on closer inspection they did not fully meet the inclusion criteria, resulting in a systematic review of 34 papers (Table 1).

Analysis was based on comparison of study details, including design, sample and setting, research focus, key results/outcomes, implications and weaknesses, as recorded in Table 1 . The analytical process focused in particular on the identification of similarities and differences in relation to these areas. Subsequent realization of the heterogeneity of these factors including the predominantly descriptive nature of design prevented the undertaking of a meta-analysis.

\section{Results}

\section{Study selection and characteristics}

Thirty-four papers fulfilled the inclusion criteria, incorporating a focus on caregiver knowledge-related needs, including communication, information and education. ${ }^{13-51}$ Study focus included pain management, in particular inadequacies in knowledge and the impact of education, $14,16,30,31,35-37,40,44,46$ caregiver-patient communication, $15,19,21,22,27,39$ caregiver-health professional communication, ${ }^{13,18,25,45}$ caregiver needs, ${ }^{23,26,29,32,34,38}$ servicerelated communication and information, ${ }^{20,33,41-43}$ and the implementation and development of interventions. 
Table 1 Key details and scores for included studies

\begin{tabular}{|c|c|c|c|c|c|c|c|c|}
\hline $\begin{array}{l}\text { Author } \\
\text { and date }\end{array}$ & Article title & Design & Sample and setting & Research focus & Results/outcomes & Implications & Weaknesses & $\begin{array}{l}\text { Score } \\
(\max \\
32)\end{array}$ \\
\hline $\begin{array}{l}\text { Aldred, et al. } \\
\qquad(2005)\end{array}$ & $\begin{array}{l}\text { Advanced heart } \\
\text { failure: impact } \\
\text { on older } \\
\text { patients and } \\
\text { informal carers }\end{array}$ & $\begin{array}{l}\text { Qualitative } \\
\text { interviews } \\
\text { of patient- } \\
\text { caregiver dyads }\end{array}$ & $\begin{array}{l}10 \text { patients with } \\
\text { stage II-IV heart } \\
\text { failure and their } \\
\text { caregivers } \\
\text { attending a } \\
\text { district general } \\
\text { hospital in the } \\
\text { UK }\end{array}$ & $\begin{array}{l}\text { Explores the } \\
\text { impact of heart } \\
\text { failure on } \\
\text { patient and } \\
\text { caregiver }\end{array}$ & $\begin{array}{l}\text { Negative impact of illness } \\
\text { compounded by lack of } \\
\text { understanding of the condition } \\
\text { and fragmented care provision, } \\
\text { facilitated by poor } \\
\text { communication, in particular } \\
\text { lack of time }\end{array}$ & $\begin{array}{l}\text { Greater need for } \\
\text { communication } \\
\text { especially } \\
\text { around } \\
\text { prognosis }\end{array}$ & $\begin{array}{l}\text { Small sample size, } \\
\text { not all } \\
\text { palliative. } \\
\text { Response bias } \\
\text { as participants } \\
\text { in better health } \\
\text { than non- } \\
\text { participants }\end{array}$ & 21 \\
\hline $\begin{array}{c}\text { Aranda, et al. } \\
(2004)\end{array}$ & $\begin{array}{l}\text { Barriers to effective } \\
\text { cancer pain } \\
\text { management: a } \\
\text { survey of } \\
\text { Australian } \\
\text { family } \\
\text { caregivers }\end{array}$ & $\begin{array}{l}\text { Descriptive, } \\
\text { exploratory } \\
\text { cross-sectional } \\
\text { study of a } \\
\text { cohort of family } \\
\text { caregivers } \\
\text { recruited over a } \\
\text { one-year } \\
\text { period. } \\
\text { Univariate and } \\
\text { bivariate } \\
\text { analysis }\end{array}$ & $\begin{array}{l}75 \text { caregivers of } \\
\text { cancer patients } \\
\text { attending } \\
\text { outpatient } \\
\text { oncology clinic } \\
\text { in a public } \\
\text { hospital. } \\
\text { Australia }\end{array}$ & $\begin{array}{l}\text { Investigates family } \\
\text { barriers to } \\
\text { effective pain } \\
\text { management }\end{array}$ & $\begin{array}{l}\text { Uncertainties about addiction, } \\
\text { disease progression, side } \\
\text { effects, and tolerance }\end{array}$ & $\begin{array}{l}\text { Need to raise } \\
\text { awareness of } \\
\text { caregivers } \\
\text { about pain } \\
\text { management }\end{array}$ & $\begin{array}{l}\text { Self-reported, } \\
\text { small sample } \\
\text { size, limitations } \\
\text { in } \\
\text { generalizability }\end{array}$ & 21 \\
\hline Beach (1995) & $\begin{array}{l}\text { Caregiver } \\
\text { discourse: } \\
\text { perceptions of } \\
\text { illness-related } \\
\text { dialogue }\end{array}$ & $\begin{array}{l}\text { Qualitative study } \\
\text { using semi- } \\
\text { structured } \\
\text { interviews and } \\
\text { content } \\
\text { analysis } \\
\text { methodology }\end{array}$ & $\begin{array}{l}10 \text { caregivers in a } \\
\text { hospice, semi- } \\
\text { structured } \\
\text { interviews. USA }\end{array}$ & $\begin{array}{l}\text { To examine how } \\
\text { caregivers } \\
\text { perceive their } \\
\text { communication } \\
\text { with dying } \\
\text { family } \\
\text { members }\end{array}$ & $\begin{array}{l}\text { Six sub-categories found: caregiver } \\
\text { denial, patient denial, second } \\
\text { guessing, previous discourse, } \\
\text { illness-related dialogue, } \\
\text { bereavement }\end{array}$ & $\begin{array}{l}\text { Need to improve } \\
\text { communication } \\
\text { in similar } \\
\text { situations and } \\
\text { track various } \\
\text { communication } \\
\text { interventions }\end{array}$ & $\begin{array}{l}\text { Small sample, all } \\
\text { female (restricts } \\
\text { generalizabil- } \\
\text { ity), single data } \\
\text { source (no } \\
\text { triangulation) }\end{array}$ & 20 \\
\hline $\begin{array}{l}\text { Berry and } \\
\text { Ward } \\
\text { (1995) }\end{array}$ & $\begin{array}{l}\text { Barriers to pain } \\
\text { management in } \\
\text { hospice: A } \\
\text { study of family } \\
\text { caregivers }\end{array}$ & $\begin{array}{l}\text { Quasi- } \\
\text { experimental } \\
\text { study using } \\
\text { validated } \\
\text { questionnaire } \\
\text { of primary } \\
\text { caregivers of } \\
\text { terminally ill } \\
\text { cancer patients } \\
\text { eligible for } \\
\text { hospice care. } \\
\text { Univariate and } \\
\text { bivariate } \\
\text { analysis }\end{array}$ & $\begin{array}{l}37 \text { caregivers } \\
\text { participated } \\
\text { (further sample } \\
\text { characteristics } \\
\text { given). } \\
\text { Recruited } \\
\text { through home } \\
\text { care-based } \\
\text { hospice } \\
\text { programme in } \\
\text { urban mid- } \\
\text { western USA }\end{array}$ & $\begin{array}{l}\text { To examine } \\
\text { concerns about } \\
\text { reporting pain } \\
\text { and using } \\
\text { analgesics in a } \\
\text { sample of } \\
\text { primary care } \\
\text { givers of } \\
\text { patients } \\
\text { receiving } \\
\text { hospice care }\end{array}$ & $\begin{array}{l}\text { Caregivers reported various } \\
\text { concerns about treatment of } \\
\text { pain (eg, addiction, side effects, } \\
\text { disease progression). Older and } \\
\text { lower educated caregivers more } \\
\text { likely to believe reporting pain } \\
\text { distracts physician from treating } \\
\text { cancer }\end{array}$ & $\begin{array}{l}\text { Understanding } \\
\text { caregiver } \\
\text { perspectives on } \\
\text { pain is } \\
\text { important in } \\
\text { developing } \\
\text { hospice } \\
\text { services and } \\
\text { services in } \\
\text { other settings }\end{array}$ & $\begin{array}{l}\text { Small sample size. } \\
\text { Interviewing } \\
\text { caregiver and } \\
\text { patient together } \\
\text { may have } \\
\text { distorted } \\
\text { results }\end{array}$ & 14 \\
\hline $\begin{array}{r}\text { Cameron, et } \\
\text { al. (2004) }\end{array}$ & $\begin{array}{l}\text { A brief problem- } \\
\text { solving } \\
\text { intervention for } \\
\text { family } \\
\text { caregivers to } \\
\text { individuals with } \\
\text { advanced } \\
\text { cancer }\end{array}$ & $\begin{array}{l}\text { Descriptive: pre- } \\
\text { and post- using } \\
\text { several tools } \\
\text { and an } \\
\text { educational } \\
\text { intervention in } \\
\text { the middle } \\
\text { (mean: } 4.8 \\
\text { weeks). } \\
\text { Analysis using }\end{array}$ & $\begin{array}{l}41 \text { out of } 105 \\
\text { caregivers, } \\
\text { Canada }\end{array}$ & $\begin{array}{l}\text { Evaluation of an } \\
\text { educational } \\
\text { intervention. } \\
\text { Measured: } \\
\text { demographics } \\
\text { including age, } \\
\text { sex and marital } \\
\text { status, problem } \\
\text { solving } \\
\text { approach, }\end{array}$ & $\begin{array}{l}\text { Problem solving methods (defining } \\
\text { problem, professional } \\
\text { assistance, help patient, } \\
\text { obstacles, adjusting). No } \\
\text { difference detected unless } \\
\text { emotional tension }\end{array}$ & $\begin{array}{l}\text { Problem solving } \\
\text { interventions } \\
\text { may have some } \\
\text { benefits }\end{array}$ & $\begin{array}{l}\text { Low uptake rates, } \\
\text { no control } \\
\text { group so } \\
\text { improvements } \\
\text { may have taken } \\
\text { place naturally }\end{array}$ & 20 \\
\hline
\end{tabular}


Table 1 (continued)

\begin{tabular}{|c|c|c|c|c|c|c|c|c|}
\hline $\begin{array}{l}\text { Author } \\
\text { and date }\end{array}$ & Article title & Design & Sample and setting & Research focus & Results/outcomes & Implications & Weaknesses & $\begin{array}{l}\text { Score } \\
\text { (max } \\
32) \\
\end{array}$ \\
\hline & & $\begin{array}{l}\text { t-test } \\
\text { and chi-square }\end{array}$ & & $\begin{array}{l}\text { emotional well } \\
\text { being, caregiver } \\
\text { assistance and } \\
\text { self-efficacy }\end{array}$ & & & & \\
\hline $\begin{array}{l}\text { Caron, et al. } \\
\quad(2005)\end{array}$ & $\begin{array}{l}\text { Decision making at } \\
\text { the end of life in } \\
\text { dementia: how } \\
\text { family } \\
\text { caregivers } \\
\text { perceive their } \\
\text { interactions } \\
\text { with health care } \\
\text { providers in } \\
\text { long term care } \\
\text { settings }\end{array}$ & $\begin{array}{l}\text { Qualitative in- } \\
\text { depth } \\
\text { interviews } \\
\text { adopting } \\
\text { grounded } \\
\text { theory } \\
\text { approach }\end{array}$ & $\begin{array}{l}24 \text { caregivers of } \\
\text { family } \\
\text { members with } \\
\text { late stage } \\
\text { dementia. } \\
\text { Recruited from } \\
\text { geriatric } \\
\text { institute and } \\
\text { long-term care } \\
\text { centres. Canada }\end{array}$ & $\begin{array}{l}\text { To examine the } \\
\text { experience and } \\
\text { preoccupations } \\
\text { of family } \\
\text { caregivers } \\
\text { about end of life } \\
\text { issues and in } \\
\text { particular about } \\
\text { treatment } \\
\text { decision- } \\
\text { making } \\
\text { processes }\end{array}$ & $\begin{array}{l}\text { Family caregivers seek a } \\
\text { personalized relationship with } \\
\text { care providers. The majority } \\
\text { expressed a need to meet more } \\
\text { often with the care team to } \\
\text { provide an understanding of the } \\
\text { evolution of the condition. Trust } \\
\text { was a key element in the } \\
\text { caregiver - professional } \\
\text { relationship and was facilitated } \\
\text { via regular contact and } \\
\text { information provision }\end{array}$ & $\begin{array}{l}\text { Health care } \\
\text { providers } \\
\text { should facilitate } \\
\text { a proactive } \\
\text { caregiver } \\
\text { approach by } \\
\text { offering } \\
\text { opportunities } \\
\text { for } \\
\text { communica- } \\
\text { tion. Long-term } \\
\text { care should } \\
\text { incorporate a } \\
\text { philosophy of } \\
\text { partnership } \\
\text { with the } \\
\text { caregiver }\end{array}$ & $\begin{array}{l}\text { Relatively small } \\
\text { sample. } \\
\text { Retrospective } \\
\text { interviews }\end{array}$ & 23 \\
\hline $\begin{array}{l}\text { Clayton, et al. } \\
\quad(2005)\end{array}$ & $\begin{array}{l}\text { The needs of } \\
\text { terminally ill } \\
\text { cancer patients } \\
\text { versus those of } \\
\text { caregivers for } \\
\text { information } \\
\text { regarding } \\
\text { prognosis and } \\
\text { end of life } \\
\text { issues }\end{array}$ & $\begin{array}{l}\text { Qualitative study } \\
\text { combining } \\
\text { focus groups, } \\
\text { face to face } \\
\text { interviews and } \\
\text { telephone } \\
\text { interviews }\end{array}$ & $\begin{array}{l}22 \text { health } \\
\text { professionals, } \\
24 \text { caregivers } \\
\text { and } 19 \text { patients } \\
\text { recruited from } \\
\text { specialist } \\
\text { palliative care } \\
\text { services. } \\
\text { Australia }\end{array}$ & $\begin{array}{l}\text { Perspective of } \\
\text { health } \\
\text { professionals, } \\
\text { patients and } \\
\text { caregivers on } \\
\text { the provision of } \\
\text { information } \\
\text { regarding } \\
\text { prognosis and } \\
\text { end of life care }\end{array}$ & $\begin{array}{l}\text { Consistent information important, } \\
\text { so that both patient and } \\
\text { caregiver had the same } \\
\text { understanding of what to } \\
\text { expect. Variation in preference } \\
\text { regarding information } \\
\text { dissemination with particular } \\
\text { regard to prognosis. Problems } \\
\text { with using interpreters were } \\
\text { highlighted. For family } \\
\text { interpreters concern was raised } \\
\text { regarding the power this gave } \\
\text { the interpreter to withhold } \\
\text { information }\end{array}$ & $\begin{array}{l}\text { Highlights } \\
\text { importance of } \\
\text { checking } \\
\text { individual } \\
\text { needs of patient } \\
\text { and caregiver } \\
\text { regarding } \\
\text { prognostic and } \\
\text { end of life } \\
\text { information as } \\
\text { they can be } \\
\text { different }\end{array}$ & $\begin{array}{l}\text { Small sample size. } \\
\text { Poor } \\
\text { generalizability. } \\
\text { Educational } \\
\text { background of } \\
\text { caregivers } \\
\text { higher than the } \\
\text { national } \\
\text { average }\end{array}$ & 20 \\
\hline $\begin{array}{l}\text { Exley, et al. } \\
\quad(2005)\end{array}$ & $\begin{array}{l}\text { Palliative care in } \\
\text { the community } \\
\text { for cancer and } \\
\text { end-stage } \\
\text { cardio- } \\
\text { respiratory } \\
\text { disease: the } \\
\text { views of } \\
\text { patients, lay- } \\
\text { carers and } \\
\text { health care } \\
\text { professionals }\end{array}$ & $\begin{array}{l}\text { Qualitative study } \\
\text { (using semi- } \\
\text { structured } \\
\text { interviews and } \\
\text { focus groups) } \\
\text { of patients, } \\
\text { caregivers and } \\
\text { health care } \\
\text { professionals, } \\
\text { comparing } \\
\text { primary } \\
\text { palliative care } \\
\text { for people with } \\
\text { advanced } \\
\text { cancer and } \\
\text { those with end- } \\
\text { stage cardio- }\end{array}$ & $\begin{array}{l}50 \text { interviews, } \\
\text { relating to } 29 \\
\text { patients, most } \\
\text { with informal } \\
\text { caregiver also } \\
\text { present. First } \\
\text { interview and } \\
\text { then follow up } \\
\text { in most cases. } \\
\text { Service } \\
\text { providers' } \\
\text { views elicited } \\
\text { from focus } \\
\text { groups (GPs, } \\
\text { district nurses, } \\
\text { specialist } \\
\text { palliative care }\end{array}$ & $\begin{array}{l}\text { Comparison of } \\
\text { primary } \\
\text { palliative care } \\
\text { provision for } \\
\text { cancer and end- } \\
\text { stage cardio- } \\
\text { respiratory } \\
\text { patients }\end{array}$ & $\begin{array}{l}\text { People with end stage cardio- } \\
\text { respiratory disease less likely to } \\
\text { receive full and easily } \\
\text { understood information; to be } \\
\text { aware that they are dying and to } \\
\text { receive district nursing care } \\
\text { than cancer patients. Also more } \\
\text { likely to experience financial } \\
\text { difficulties. They are the } \\
\text { 'disadvantaged dying' }\end{array}$ & $\begin{array}{l}\text { Findings echo } \\
\text { other studies. } \\
\text { Need to } \\
\text { develop } \\
\text { services and } \\
\text { increase } \\
\text { uptake/access }\end{array}$ & $\begin{array}{l}\text { Small-scale study } \\
\text { that is not } \\
\text { easily } \\
\text { generalizable. } \\
\text { Some problems } \\
\text { identifying } \\
\text { participants and } \\
\text { a longer gap } \\
\text { needed } \\
\text { between } \\
\text { interviews }\end{array}$ & 21 \\
\hline
\end{tabular}


Table 1 (continued)

\begin{tabular}{|c|c|c|c|c|c|c|c|c|}
\hline $\begin{array}{l}\text { Author } \\
\text { and date }\end{array}$ & Article title & Design & Sample and setting & Research focus & Results/outcomes & Implications & Weaknesses & $\begin{array}{l}\text { Score } \\
\text { (max } \\
32)\end{array}$ \\
\hline & & $\begin{array}{l}\text { respiratory } \\
\text { disease }\end{array}$ & $\begin{array}{l}\text { community } \\
\text { nurses and } \\
\text { occupational } \\
\text { therapists). } \\
\text { Number of } \\
\text { participants not } \\
\text { specified }\end{array}$ & & & & & \\
\hline $\begin{array}{l}\text { Field, et al. } \\
\text { (1995) }\end{array}$ & $\begin{array}{l}\text { Terminal illness: } \\
\text { views of } \\
\text { patients and } \\
\text { their lay carers }\end{array}$ & $\begin{array}{l}\text { Cross-sectional, } \\
\text { descriptive. } \\
\text { Semi- } \\
\text { structured } \\
\text { interviews } \\
\text { conducted with } \\
\text { patients and } \\
\text { caregivers }\end{array}$ & $\begin{array}{l}\text { Interviews with } 28 \\
\text { terminally ill } \\
\text { patients at } \\
\text { hospice and } \\
\text { their } \\
\text { caregivers, } \\
\text { Leicestershire }\end{array}$ & $\begin{array}{l}\text { Comparison of } \\
\text { patient and } \\
\text { caregiver } \\
\text { perceptions of } \\
\text { patient } \\
\text { experiences } \\
\text { leading to } \\
\text { hospice } \\
\text { admission: } \\
\text { symptoms, } \\
\text { activities of } \\
\text { daily living and } \\
\text { perceptions of } \\
\text { care }\end{array}$ & $\begin{array}{l}\text { Agreement on the perception of } \\
\text { need for daily activities; } \\
\text { divergence in psychological } \\
\text { symptoms, distress and the } \\
\text { number of main symptoms }\end{array}$ & $\begin{array}{l}\text { Information } \\
\text { obtained from } \\
\text { caregivers is } \\
\text { valid proxy }\end{array}$ & $\begin{array}{l}\text { Small sample size, } \\
\text { questions } \\
\text { regarding } \\
\text { reliability of } \\
\text { measures) }\end{array}$ & 23 \\
\hline $\begin{array}{l}\text { Fine and } \\
\text { Busch } \\
\text { (1998) }\end{array}$ & $\begin{array}{l}\text { Characterization of } \\
\text { breakthrough } \\
\text { pain by hospice } \\
\text { patients and } \\
\text { their caregivers }\end{array}$ & $\begin{array}{l}\text { Descriptive study } \\
\text { using survey } \\
\text { and qualitative } \\
\text { methods } \\
\text { comparing } \\
\text { breakthrough } \\
\text { pain } \\
\text { experienced by } \\
\text { patients and } \\
\text { caregivers } \\
\text { perceptions of it }\end{array}$ & $\begin{array}{l}22 \text { hospice patients } \\
\text { with advanced } \\
\text { cancer and } \\
\text { caregivers (19 } \\
\text { experienced } \\
\text { breakthrough } \\
\text { pain and } \\
\text { therefore } \\
\text { included) } \\
\text { Recruited } \\
\text { through } \\
\text { Hospice in Salt } \\
\text { Lake City, Utah, } \\
\text { USA }\end{array}$ & $\begin{array}{l}\text { Investigates the } \\
\text { nature- } \\
\text { occurrence, } \\
\text { duration, } \\
\text { perception of } \\
\text { intensity, } \\
\text { amount and } \\
\text { time of relief - } \\
\text { of breakthrough } \\
\text { pain (intense } \\
\text { episodic pain) } \\
\text { experienced by } \\
\text { patients; } \\
\text { compares with } \\
\text { caregivers } \\
\text { perceptions }\end{array}$ & $\begin{array}{l}86 \% \text { of sample experienced } \\
\text { breakthrough pain, } 2.9 \text { times per } \\
24 \text { hours. Mean pain intensity of } \\
7(1-10) \text { lasting average of } 52 \\
\text { minutes and } 30 \text { minutes until } \\
\text { relief. Caregivers underestimate } \\
\text { experience of breakthrough } \\
\text { pain in patients }\end{array}$ & $\begin{array}{l}\text { Suggests need to } \\
\text { develop oral } \\
\text { analgesic } \\
\text { provision for } \\
\text { more optimal } \\
\text { management of } \\
\text { breakthrough } \\
\text { pain }\end{array}$ & $\begin{array}{l}\text { Small sample size } \\
\text { limits } \\
\text { generalizability. } \\
\text { Breakthrough } \\
\text { pain may have } \\
\text { been under/ } \\
\text { over estimated, } \\
\text { qualifying } \\
\text { conclusions }\end{array}$ & 14 \\
\hline Fukui (2004) & $\begin{array}{l}\text { Information needs } \\
\text { and the related } \\
\text { variables of } \\
\text { Japanese } \\
\text { family } \\
\text { caregivers of } \\
\text { terminally ill } \\
\text { cancer patients }\end{array}$ & $\begin{array}{l}\text { Descriptive, } \\
\text { structured } \\
\text { interview/quasi- } \\
\text { experimental } \\
\text { design using } \\
\text { questionnaires }\end{array}$ & $\begin{array}{l}66 \text { Japanese } \\
\text { caregivers in a } \\
\text { pall care unit. } \\
\text { Measures: } \\
\text { demographics } \\
\text { including age } \\
\text { and sex, patient } \\
\text { functional } \\
\text { status, } \\
\text { situational } \\
\text { variables. } \\
\text { Rating of } \\
\text { information } \\
\text { need }\end{array}$ & $\begin{array}{l}\text { Examined the } \\
\text { information } \\
\text { needs of family } \\
\text { caregivers of } \\
\text { terminally ill } \\
\text { cancer patients }\end{array}$ & $\begin{array}{l}\text { 'Disease-related' and 'care-related' } \\
\text { informational needs; } 73 \% \\
\text { wanted disease-related info } \\
\text { (cancer, treatment, prognosis) } \\
\quad+<50 \% \text { required care-related } \\
\text { info; determinants have been } \\
\text { analysed }\end{array}$ & $\begin{array}{l}\text { Providing } \\
\text { information to } \\
\text { caregivers, } \\
\text { weak } \\
\text { generalizability. } \\
\text { Younger family } \\
\text { caregivers may } \\
\text { require greater } \\
\text { focus from HPs } \\
\text { on their } \\
\text { information } \\
\text { needs } \\
\text { regarding the } \\
\text { patient's }\end{array}$ & $\begin{array}{l}\text { Small convenience } \\
\text { sample, low } \\
\text { response rate }\end{array}$ & 23 \\
\hline
\end{tabular}


Table 1 (continued)

\begin{tabular}{|c|c|c|c|c|c|c|c|c|}
\hline $\begin{array}{l}\text { Author } \\
\text { and date }\end{array}$ & Article title & Design & Sample and setting & Research focus & Results/outcomes & Implications & Weaknesses & $\begin{array}{l}\text { Score } \\
\text { (max } \\
32 \text { ) }\end{array}$ \\
\hline $\begin{array}{l}\text { Gagnon, et al. } \\
\quad(2002)\end{array}$ & $\begin{array}{l}\text { Delirium in } \\
\text { advanced } \\
\text { cancer: a } \\
\text { psycho } \\
\text { educational } \\
\text { intervention for } \\
\text { family } \\
\text { caregivers }\end{array}$ & $\begin{array}{l}\text { Mixed: qualitative } \\
\text { and } \\
\text { quantitative; } \\
\text { descriptive } \\
\text { observational }\end{array}$ & $\begin{array}{l}\text { Three phases: } \\
\text { generating } \\
\text { themes ( } 21 \\
\text { caregivers+11 } \\
\text { professionals), } \\
\text { developing first } \\
\text { version of } \\
\text { brochure ( } 20 \\
\text { caregivers), } \\
\text { intervention (58 } \\
\text { control and } 66 \\
\text { caregivers), } \\
\text { Canada }\end{array}$ & $\begin{array}{l}\text { Evaluation of the } \\
\text { implementation } \\
\text { of a psycho } \\
\text { educational } \\
\text { intervention in } \\
\text { a palliative care } \\
\text { hospice to help } \\
\text { family } \\
\text { caregivers cope } \\
\text { with delirium }\end{array}$ & $\begin{array}{l}\text { Intervention had some positive } \\
\text { effects on caregivers' } \\
\text { perception about delirium, } \\
\text { especially if delivered in earlier } \\
\text { phase of cancer - had greater } \\
\text { knowledge and experienced } \\
\text { less misunderstanding. No } \\
\text { improvement in mood }\end{array}$ & $\begin{array}{l}\text { disease and } \\
\text { treatment } \\
\text { Integrated in } \\
\text { palliative care } \\
\text { services in the } \\
\text { region, } \\
\text { satisfying } \\
\text { caregivers' } \\
\text { information } \\
\text { needs - should } \\
\text { be targeted in } \\
\text { use }\end{array}$ & $\begin{array}{c}\text { Non-randomized, } \\
\text { small sample }\end{array}$ & 22 \\
\hline $\begin{array}{l}\text { Harding, et al. } \\
\quad(2004)\end{array}$ & $\begin{array}{l}\text { Evaluation of a } \\
\text { short-term } \\
\text { group } \\
\text { intervention for } \\
\text { informal carers } \\
\text { of patients } \\
\text { attending a } \\
\text { home palliative } \\
\text { care service }\end{array}$ & $\begin{array}{l}\text { Quasi- } \\
\text { experimental. } \\
\text { Prospective and } \\
\text { observational } \\
\text { evaluation, } \\
\text { using both } \\
\text { qualitative and } \\
\text { quantitative } \\
\text { methods. } \\
\text { Involved } \\
\text { comparison of } \\
\text { intervention } \\
\text { with non- } \\
\text { intervention } \\
\text { group (ie, like } \\
\text { control). Used } \\
\text { various } \\
\text { validated } \\
\text { outcome } \\
\text { measures. } \\
\text { Univariate and } \\
\text { multivariate } \\
\text { analysis of } \\
\text { results }\end{array}$ & $\begin{array}{l}73 \text { caregivers: } 36 \\
\text { attended the } \\
\text { intervention; } 37 \\
\text { declined; but } \\
\text { attrition of } \\
\text { numbers in } \\
\text { follow-up } \\
\text { sessions. Study } \\
\text { undertaken } \\
\text { with two } \\
\text { palliative care } \\
\text { home services } \\
\text { in London }\end{array}$ & $\begin{array}{l}\text { Evaluation of } \\
\text { service } \\
\text { intervention } \\
\text { "The } 90 \text { minute } \\
\text { group" which } \\
\text { combined } \\
\text { informal } \\
\text { multiprofes- } \\
\text { sional teaching } \\
\text { with facilitated } \\
\text { peer exchange } \\
\text { and support }\end{array}$ & $\begin{array}{l}\text { Evaluation suggested that patients } \\
\text { in intervention group gained } \\
\text { from support and knowledge } \\
\text { provided by 90- minute group, } \\
\text { awhile they participated. } \\
\text { Attrition (of nos. involved) } \\
\text { prevented analysis of impact on } \\
\text { 'global psychological scores' }\end{array}$ & $\begin{array}{l}\text { Study } \\
\text { demonstrates } \\
\text { need for } \\
\text { rigorous } \\
\text { evaluation of } \\
\text { interventions } \\
\text { for caregivers } \\
\text { (but also } \\
\text { demonstrates } \\
\text { some of } \\
\text { problems). } \\
\text { Lessons for } \\
\text { future } \\
\text { evaluations } \\
\text { discussed }\end{array}$ & $\begin{array}{l}\text { Modest sample } \\
\text { size with } \\
\text { attrition } \\
\text { problems. } \\
\text { Some of } \\
\text { limitations not } \\
\text { recognized until } \\
\text { post study }\end{array}$ & 18 \\
\hline $\begin{array}{l}\text { Harrington, et } \\
\text { al. (1996) }\end{array}$ & $\begin{array}{l}\text { Needs of } \\
\text { caregivers of } \\
\text { clinic and } \\
\text { hospice cancer } \\
\text { patients }\end{array}$ & $\begin{array}{l}\text { Prospective, } \\
\text { correlational } \\
\text { study involving } \\
\text { caregiver } \\
\text { completion of } \\
\text { the Home } \\
\text { Caregiver } \\
\text { Needs Survey } \\
\text { (HCNA) }\end{array}$ & $\begin{array}{l}55 \text { caregivers of } \\
\text { clinic cancer } \\
\text { patients (25) } \\
\text { and hospice } \\
\text { patients (30); in } \\
\text { rural and urban } \\
\text { setting in USA } \\
\text { using the HCNA } \\
\text { tool. Mean } \\
\text { ages: } 51 \text { and } 56 \\
\text { years } \\
\text { respectively, } 17 \\
\text { female in the }\end{array}$ & $\begin{array}{l}\text { Comparison of the } \\
\text { self-identified } \\
\text { needs of } \\
\text { caregivers of } \\
\text { patients who } \\
\text { were either } \\
\text { clinic or } \\
\text { hospice based }\end{array}$ & $\begin{array}{l}\text { Information and spiritual needs as } \\
\text { the most important needs. } \\
\text { Spirituality suggested as key } \\
\text { element in the caregiver's } \\
\text { coping strategies in taking care } \\
\text { of the cancer patient }\end{array}$ & $\begin{array}{l}\text { Providing } \\
\text { information } \\
\text { needs, referring } \\
\text { to appropriate } \\
\text { community } \\
\text { agencies, } \\
\text { helping } \\
\text { caregivers to } \\
\text { satisfy their } \\
\text { needs. } \\
\text { Information } \\
\text { should be } \\
\text { individualized }\end{array}$ & $\begin{array}{l}\text { Failure to control } \\
\text { for type of } \\
\text { cancer } \\
\text { diagnosis, } \\
\text { length of } \\
\text { disease process } \\
\text { and patient } \\
\text { level of } \\
\text { dependency. } \\
\text { Sample size too } \\
\text { small }\end{array}$ & 25 \\
\hline
\end{tabular}


Table 1 (continued)

\begin{tabular}{|c|c|c|c|c|c|c|c|c|}
\hline $\begin{array}{l}\text { Author } \\
\text { and date }\end{array}$ & Article title & Design & Sample and setting & Research focus & Results/outcomes & Implications & Weaknesses & $\begin{array}{l}\text { Score } \\
\text { (max } \\
32)\end{array}$ \\
\hline & & & $\begin{array}{l}\text { latter and } 23 \text { in } \\
\text { the former. } 8 \\
\text { were spouses } \\
\text { in the former } \\
\text { and } 15 \text { were in } \\
\text { the latter. } \\
\text { Measures: } \\
\text { caregiver } \\
\text { needs, demos }\end{array}$ & & & $\begin{array}{l}\text { for the } \\
\text { caregiver based } \\
\text { on the stage of } \\
\text { illness and the } \\
\text { concerns of the } \\
\text { caregiver. } \\
\text { Suggests } \\
\text { development of } \\
\text { information } \\
\text { assessment } \\
\text { instruments }\end{array}$ & & \\
\hline $\begin{array}{l}\text { Hauser, et al. } \\
\qquad(2006)\end{array}$ & $\begin{array}{l}\text { Who's caring for } \\
\text { whom? } \\
\text { Differing } \\
\text { perspectives } \\
\text { between } \\
\text { seriously ill } \\
\text { patients and } \\
\text { their family } \\
\text { caregivers }\end{array}$ & $\begin{array}{l}\text { Quantitative study } \\
\text { comprising } \\
\text { administration } \\
\text { of survey to } \\
\text { both individuals } \\
\text { in each dyad }\end{array}$ & $\begin{array}{l}988 \text { patients, } 893 \\
\text { caregivers, } \\
\text { multiple } \\
\text { disorders } \\
\text { including } \\
\text { cancer, heart } \\
\text { disease and } \\
\text { COPD. USA }\end{array}$ & $\begin{array}{l}\text { Aims to investigate } \\
\text { concordance } \\
\text { between patient } \\
\text { and caregiver } \\
\text { views regarding } \\
\text { end of life care }\end{array}$ & $\begin{array}{l}52 \% \text { agreement regarding levels of } \\
\text { pain. } 57 \% \text { agreement regarding } \\
\text { levels of patient activity. Lower } \\
\text { proportion of caregivers (15\%) } \\
\text { reported needing further care } \\
\text { support at home compared to } \\
\text { patients ( } 30 \% \text { ). Overall patients } \\
\text { reporting higher care needs that } \\
\text { did caregivers. } 66 \% \text { agreement } \\
\text { regarding high level of trust in } \\
\text { physician, for remainder, } \\
\text { majority of cases, caregiver had } \\
\text { less trust than patient. } 48 \% \\
\text { agreement regarding clarity of } \\
\text { information on prognosis, again } \\
\text { for majority, caregiver was } \\
\text { more dissatisfied. Similar } \\
\text { pattern for information relating } \\
\text { to side effects (51\% agreement) } \\
\text { and whether physician listened } \\
\text { (62\% agreement) }\end{array}$ & $\begin{array}{l}\text { Professionals need } \\
\text { to recognize } \\
\text { that patients } \\
\text { report different } \\
\text { - and often } \\
\text { higher - care } \\
\text { needs than the } \\
\text { caregivers }\end{array}$ & $\begin{array}{l}\text { Excluded patients } \\
\text { with dementia } \\
\text { and AIDS }\end{array}$ & 22 \\
\hline $\begin{array}{l}\text { Hudson, et al. } \\
\quad(2002)\end{array}$ & $\begin{array}{l}\text { Intervention } \\
\text { development } \\
\text { for enhanced } \\
\text { lay palliative } \\
\text { caregiver } \\
\text { support - the } \\
\text { use of focus } \\
\text { groups }\end{array}$ & $\begin{array}{l}\text { Phase one } \\
\text { (intervention } \\
\text { development) } \\
\text { of three-stage } \\
\text { strategy for } \\
\text { developing } \\
\text { nursing } \\
\text { intervention. } \\
\text { Qualitative } \\
\text { focus group } \\
\text { study } \\
\text { (moderated); } \\
\text { code-based } \\
\text { content } \\
\text { analysis of data }\end{array}$ & $\begin{array}{l}\text { Three focus } \\
\text { groups: } \\
\text { palliative care } \\
\text { nurses (7 } \\
\text { participants); } \\
\text { bereaved } \\
\text { caregivers (8 } \\
\text { participants); } \\
\text { current } \\
\text { caregivers (6 } \\
\text { participants). } \\
\text { Melbourne, } \\
\text { Australia }\end{array}$ & $\begin{array}{l}\text { Needs-based study } \\
\text { towards } \\
\text { development of } \\
\text { new nursing } \\
\text { intervention } \\
\text { focusing on } \\
\text { guidance and } \\
\text { support } \\
\text { provided for lay } \\
\text { caregivers }\end{array}$ & $\begin{array}{l}\text { Caregivers felt unprepared in role } \\
\text { and wanted more support from } \\
\text { health professionals: verbal and } \\
\text { written information on how to } \\
\text { care; how to plan and prepare } \\
\text { for future }\end{array}$ & $\begin{array}{l}\text { Findings confirm } \\
\text { prior research } \\
\text { and feed into } \\
\text { development of } \\
\text { new nursing } \\
\text { intervention } \\
\text { (being } \\
\text { evaluated by } \\
\text { RCT study) }\end{array}$ & $\begin{array}{l}\text { Small sample, not } \\
\text { easily } \\
\text { generalizable }\end{array}$ & 23 \\
\hline $\begin{array}{c}\text { Jansma, et al. } \\
(2005)\end{array}$ & $\begin{array}{l}\text { Support } \\
\text { requirements } \\
\text { for caregivers } \\
\text { of patients with }\end{array}$ & $\begin{array}{l}\text { Descriptive, cross- } \\
\text { sectional; } \\
\text { qualitative and } \\
\text { survey }\end{array}$ & $\begin{array}{l}26 \text { interviews (in } \\
\text { two stages) and } \\
50 \text { caregivers in } \\
\text { survey. } \\
\text { Netherlands }\end{array}$ & $\begin{array}{l}\text { To identify the } \\
\text { needs of } \\
\text { caregivers of } \\
\text { palliative } \\
\text { cancer patients }\end{array}$ & $\begin{array}{l}\text { Caregivers' needs: communication, } \\
\text { practical information, } \\
\text { caregivers' health and social } \\
\text { network }\end{array}$ & $\begin{array}{l}\text { Providing support } \\
\text { programmes to } \\
\text { respond } \\
\text { caregivers' } \\
\text { needs }\end{array}$ & $\begin{array}{l}\text { Majority of the data } \\
\text { were } \\
\text { retrospective, } \\
\text { suggesting } \\
\text { recall bias and }\end{array}$ & 20 \\
\hline
\end{tabular}


Table 1 (continued)

\begin{tabular}{|c|c|c|c|c|c|c|c|c|}
\hline $\begin{array}{l}\text { Author } \\
\text { and date }\end{array}$ & Article title & Design & Sample and setting & Research focus & Results/outcomes & Implications & Weaknesses & $\begin{array}{l}\text { Score } \\
\text { (max } \\
32 \text { ) }\end{array}$ \\
\hline & $\begin{array}{l}\text { palliative } \\
\text { cancer }\end{array}$ & & & $\begin{array}{l}\text { and how to } \\
\text { address these } \\
\text { needs with a } \\
\text { support } \\
\text { programme }\end{array}$ & & & $\begin{array}{l}\text { also the } \\
\text { questionnaire } \\
\text { was completely } \\
\text { self-devised } \\
\text { without any } \\
\text { validation }\end{array}$ & \\
\hline $\begin{array}{c}\text { Kasanowski } \\
\text { (1998) }\end{array}$ & $\begin{array}{l}\text { Family caregivers } \\
\text { medication } \\
\text { management of } \\
\text { symptoms in } \\
\text { patients with } \\
\text { cancer near } \\
\text { death }\end{array}$ & $\begin{array}{l}\text { Qualitative study } \\
\text { using in-depth } \\
\text { interviews. } \\
\text { Grounded } \\
\text { theory method } \\
\text { of analysis } \\
\text { (constant } \\
\text { comparative } \\
\text { method) }\end{array}$ & $\begin{array}{l}17 \text { female } \\
\text { caregivers of } \\
\text { patients with } \\
\text { cancer. USA }\end{array}$ & $\begin{array}{l}\text { Aim to understand } \\
\text { the process of } \\
\text { medicating for } \\
\text { management of } \\
\text { symptoms, in } \\
\text { cancer patients } \\
\text { near death, } \\
\text { from the } \\
\text { caregiver } \\
\text { perspective }\end{array}$ & $\begin{array}{l}\text { Degree of uncertainty in caregiver } \\
\text { role, increased by confusion } \\
\text { about the different types of } \\
\text { medication, indications for their } \\
\text { use, time for medication } \\
\text { administration and the desired } \\
\text { effect on the patient. Confidence } \\
\text { increased via verbal and/or } \\
\text { written information and } \\
\text { ongoing nursing evaluations to } \\
\text { familiarize caregivers with the } \\
\text { medications }\end{array}$ & $\begin{array}{l}\text { Need for better } \\
\text { quality } \\
\text { information to } \\
\text { enable family } \\
\text { caregivers to } \\
\text { manage } \\
\text { medication }\end{array}$ & $\begin{array}{l}\text { Small sample size, } \\
\text { limited ethnic } \\
\text { mix and single } \\
\text { hospice }\end{array}$ & 16 \\
\hline $\begin{array}{c}\text { Keefe, et al. } \\
\quad(2005)\end{array}$ & $\begin{array}{l}\text { Partner guided } \\
\text { cancer pain } \\
\text { management at } \\
\text { the end of life: } \\
\text { A preliminary } \\
\text { study }\end{array}$ & $\begin{array}{l}\text { Random } \\
\text { assignment of } \\
\text { pairs to either } \\
\text { standard care } \\
\text { or partner } \\
\text { guided pain } \\
\text { management } \\
\text { training (nurse } \\
\text { led home visits } \\
\text { focusing on } \\
\text { education } \\
\text { around pain } \\
\text { management } \\
\text { and } \\
\text { enhancement } \\
\text { of coping } \\
\text { skills). Multiple } \\
\text { measures taken } \\
\text { via telephone } \\
\text { interview }\end{array}$ & $\begin{array}{l}78 \text { cancer patients } \\
\text { and their } \\
\text { caregivers } \\
\text { recruited from } \\
\text { two cancer } \\
\text { centres. } 41 \\
\text { assigned to } \\
\text { intervention, } 37 \\
\text { to standard } \\
\text { care. USA }\end{array}$ & $\begin{array}{l}\text { Test the feasibility } \\
\text { of a new, } \\
\text { partner guided } \\
\text { pain } \\
\text { management } \\
\text { training } \\
\text { protocol that } \\
\text { integrates } \\
\text { educational } \\
\text { information } \\
\text { about cancer } \\
\text { pain with } \\
\text { systematic } \\
\text { training of } \\
\text { patients and } \\
\text { partners in } \\
\text { cognitive and } \\
\text { behavioural } \\
\text { pain coping } \\
\text { skills }\end{array}$ & $\begin{array}{l}\text { No significant treatment effects for } \\
\text { patients ratings of usual pain } \\
{[F(1,54)=1.21, P=0.028] \text { and }} \\
\text { worst pain }[F(1,56)=0.81 \text {, } \\
P=0.037] \text {. Partners receiving } \\
\text { the intervention reported } \\
\text { significantly higher levels of } \\
\text { self-efficacy for helping the } \\
\text { patient control pain } \\
{[F(1,53)=8.14 . P=0.006] \text { and for }} \\
\text { controlling other symptoms } \\
{[F(1,53) . P=0.012] \text {. }}\end{array}$ & $\begin{array}{l}\text { Highlights the } \\
\text { value of partner } \\
\text { and patient } \\
\text { focused } \\
\text { interventions in } \\
\text { improving } \\
\text { partner self- } \\
\text { efficacy and } \\
\text { therefore the } \\
\text { potential to } \\
\text { improve pain } \\
\text { management }\end{array}$ & $\begin{array}{l}\text { Low response rate } \\
\text { suggests } \\
\text { potential bias. } \\
\text { Relatively small } \\
\text { sample, in light } \\
\text { of drop out rate }\end{array}$ & 22 \\
\hline $\begin{array}{l}\text { Kessler, et al. } \\
(2005)\end{array}$ & $\begin{array}{l}\text { Social class and } \\
\text { access to } \\
\text { specialist } \\
\text { palliative care } \\
\text { services }\end{array}$ & $\begin{array}{l}\text { Cross sectional } \\
\text { survey and } \\
\text { subsample of } \\
\text { in-depth } \\
\text { interviews with } \\
\text { caregivers }\end{array}$ & $\begin{array}{l}960 \text { cancer deaths } \\
\text { reviewed 1999- } \\
2002 . \\
\text { Subsample of } \\
18 \text { caregivers } \\
\text { completed in- } \\
\text { depth } \\
\text { interview. UK }\end{array}$ & $\begin{array}{l}\text { Determine the } \\
\text { association } \\
\text { between social } \\
\text { class and place } \\
\text { of death. } \\
\text { Qualitative } \\
\text { focus on the } \\
\text { experience and } \\
\text { beliefs of } \\
\text { caregivers of } \\
\text { patients of } \\
\text { lower socio } \\
\text { economic } \\
\text { status, in }\end{array}$ & $\begin{array}{l}\text { Anxiety was influenced by level of } \\
\text { available information and } \\
\text { associated perception of } \\
\text { control. Most caregivers } \\
\text { described a decrease in anxiety } \\
\text { when they were able to access } \\
\text { high-quality information. } \\
\text { Shared information resulted in } \\
\text { lower levels of caregiver } \\
\text { anxiety. In contrast, some } \\
\text { patients kept exclusive control } \\
\text { of information by always seeing } \\
\text { the doctor alone, leaving their } \\
\text { caregivers to search for their }\end{array}$ & $\begin{array}{l}\text { Among lower } \\
\text { socio-economic } \\
\text { classes, } \\
\text { caregiver } \\
\text { anxiety will be } \\
\text { lower in } \\
\text { instances } \\
\text { where } \\
\text { information is } \\
\text { share between } \\
\text { caregiver and } \\
\text { patient }\end{array}$ & $\begin{array}{l}\text { Small sample size. } \\
\text { Variable time } \\
\text { between } \\
\text { bereavement } \\
\text { and interview } \\
\text { and nature of } \\
\text { relationship } \\
\text { between patient } \\
\text { and caregiver } \\
\text { may impact } \\
\text { considerably } \\
\text { upon } \\
\text { generalizability }\end{array}$ & 17 \\
\hline
\end{tabular}


Table 1 (continued)

\begin{tabular}{|c|c|c|c|c|c|c|c|c|}
\hline $\begin{array}{l}\text { Author } \\
\text { and date }\end{array}$ & Article title & Design & Sample and setting & Research focus & Results/outcomes & Implications & Weaknesses & $\begin{array}{l}\text { Score } \\
(\max \\
32) \\
\end{array}$ \\
\hline & & & & $\begin{array}{l}\text { particular } \\
\text { anxiety and } \\
\text { perceptions of } \\
\text { control }\end{array}$ & $\begin{array}{l}\text { own second hand information, } \\
\text { often without success. These } \\
\text { differences were not class } \\
\text { related }\end{array}$ & & & \\
\hline $\begin{array}{l}\text { Koffman and } \\
\text { Higginson } \\
(2001)\end{array}$ & $\begin{array}{l}\text { Accounts of carers' } \\
\text { satisfaction } \\
\text { with health care } \\
\text { at the end of } \\
\text { life: a } \\
\text { comparison of } \\
\text { first generation } \\
\text { black } \\
\text { Caribbeans and } \\
\text { white patients } \\
\text { with advanced } \\
\text { disease }\end{array}$ & $\begin{array}{l}\text { Survey-based } \\
\text { study } \\
\text { comparing the } \\
\text { satisfaction } \\
\text { with health care } \\
\text { at the end of life } \\
\text { of informal } \\
\text { caregivers of } \\
\text { Black } \\
\text { Caribbean and } \\
\text { 'white' patients } \\
\text { with advanced } \\
\text { progressive } \\
\text { disease during } \\
\text { last year of life. } \\
\text { Used } \\
\text { retrospective } \\
\text { (i.e post death) } \\
\text { survey } \\
\text { (structured } \\
\text { interview, but } \\
\text { included some } \\
\text { open question } \\
\text { for qualitative } \\
\text { analysis) as } \\
\text { utilized in other } \\
\text { studies; } \\
\text { includes } \\
\text { univariate } \\
\text { statistical and } \\
\text { qualitative } \\
\text { content } \\
\text { analyses }\end{array}$ & $\begin{array}{l}\text { Surveyed } 50 \\
\text { caregivers of } \\
\text { Black } \\
\text { Caribbean } \\
\text { (Caribbean } \\
\text { born) and } 50 \\
\text { caregivers of } \\
\text { 'white' (UK } \\
\text { born); further } \\
\text { characteristics } \\
\text { of sample } \\
\text { described in } \\
\text { paper. Survey } \\
\text { took place in } \\
\text { inner-London } \\
\text { boroughs of } \\
\text { Lambeth, } \\
\text { Southwark and } \\
\text { Lewisham, UK, } \\
\text { December 1997 } \\
\text { to November } \\
\text { 1998 }\end{array}$ & $\begin{array}{l}\text { Comparison of } \\
\text { informal } \\
\text { caregivers of } \\
\text { Black } \\
\text { Caribbean and } \\
\text { 'white' patients } \\
\text { satisfaction } \\
\text { with service } \\
\text { provision in } \\
\text { both primary } \\
\text { care and acute } \\
\text { settings among }\end{array}$ & $\begin{array}{l}\text { A larger proportion of respondents } \\
\text { representing the view of black } \\
\text { Caribbean patients expressed } \\
\text { dissatisfaction with care than } \\
\text { white patients. Particularly the } \\
\text { case in primary care settings. } \\
\text { Fewer black Caribbean patients } \\
\text { accessed specialist palliative } \\
\text { care services or hospices }\end{array}$ & $\begin{array}{l}\text { Results suggest } \\
\text { need for health } \\
\text { care } \\
\text { professionals to } \\
\text { communicate } \\
\text { more fully with } \\
\text { caregivers and } \\
\text { patients; further } \\
\text { education and } \\
\text { training of } \\
\text { health care } \\
\text { professionals in } \\
\text { principles of } \\
\text { inclusive } \\
\text { palliative care }\end{array}$ & $\begin{array}{l}\text { Relatively low } \\
\text { response rates. } \\
\text { Satisfaction } \\
\text { measures were } \\
\text { a relatively } \\
\text { insensitive tool } \\
\text { for health } \\
\text { service } \\
\text { evaluation }\end{array}$ & 22 \\
\hline $\begin{array}{l}\text { Lecouturier, } \\
\text { et al. } \\
\text { (1999) }\end{array}$ & $\begin{array}{l}\text { Lay carers' } \\
\text { satisfaction } \\
\text { with } \\
\text { community } \\
\text { palliative care: } \\
\text { results of a } \\
\text { postal survey. } \\
\text { South Tyneside } \\
\text { MAAG } \\
\text { Palliative Care } \\
\text { Study Group }\end{array}$ & $\begin{array}{l}\text { Feasibility study, } \\
\text { using } \\
\text { retrospective } \\
\text { postal } \\
\text { questionnaires } \\
\text { to assess the } \\
\text { satisfaction of } \\
\text { caregivers with } \\
\text { services } \\
\text { provided for } \\
\text { end of life } \\
\text { cancer patients. } \\
\text { Psychometri- } \\
\text { cally developed } \\
\text { postal }\end{array}$ & $\begin{array}{l}156 \text { completed the } \\
\text { survey (44\% } \\
\text { response from } \\
255 \text { contacted). } \\
\text { Identified via } \\
\text { death register. } \\
\text { Stratified } \\
\text { sample. South } \\
\text { Tyneside, UK }\end{array}$ & $\begin{array}{l}\text { Investigates the } \\
\text { quality of } \\
\text { information } \\
\text { provided by } \\
\text { health } \\
\text { professionals } \\
\text { and the quality } \\
\text { of services from } \\
\text { perspective of } \\
\text { lay caregivers }\end{array}$ & $\begin{array}{l}\text { (a) Substantive: information } \\
\text { provision deemed } \\
\text { unsatisfactory and } \\
\text { dissatisfaction at care provided } \\
\text { by hospitals district nurses and } \\
\text { GPs was common. } \\
\text { (b) Methodological: Postal } \\
\text { questionnaire is a valid and cost } \\
\text { effective method for assessing } \\
\text { the quality of care }\end{array}$ & $\begin{array}{l}\text { Survey offers } \\
\text { baseline } \\
\text { against which } \\
\text { improvements } \\
\text { in care can be } \\
\text { measured }\end{array}$ & $\begin{array}{l}\text { Relatively low } \\
\text { response rate } \\
\text { from } \\
\text { questionnaire. } \\
\text { Study was } \\
\text { retrospective } \\
\text { and caregiver } \\
\text { assessments } \\
\text { may have been } \\
\text { affected by } \\
\text { post- } \\
\text { bereavement } \\
\text { psychological } \\
\text { status. District }\end{array}$ & 21 \\
\hline
\end{tabular}


Table 1 (continued)

\begin{tabular}{|c|c|c|c|c|c|c|c|c|}
\hline $\begin{array}{l}\text { Author } \\
\text { and date }\end{array}$ & Article title & Design & Sample and setting & Research focus & Results/outcomes & Implications & Weaknesses & $\begin{array}{l}\text { Score } \\
\text { (max } \\
32)\end{array}$ \\
\hline & & $\begin{array}{l}\text { questionnaire } \\
\text { (described in } \\
\text { another paper). } \\
\text { Univariate and } \\
\text { bivariate } \\
\text { analysis of } \\
\text { results }\end{array}$ & & & & & $\begin{array}{l}\text { (ie, locally) } \\
\text { based study }\end{array}$ & \\
\hline $\operatorname{Lin}(2000)$ & $\begin{array}{l}\text { Barriers to the } \\
\text { analgesic } \\
\text { management of } \\
\text { cancer pain: a } \\
\text { comparison of } \\
\text { attitudes of } \\
\text { Taiwanese } \\
\text { patients and } \\
\text { their family } \\
\text { caregivers }\end{array}$ & $\begin{array}{l}\text { Quasi- } \\
\text { experimental } \\
\text { study using } \\
\text { validated } \\
\text { questionnaire } \\
\text { surveys, pain } \\
\text { inventories and } \\
\text { a performance } \\
\text { status scale to } \\
\text { assess barriers } \\
\text { to pain } \\
\text { management }\end{array}$ & $\begin{array}{l}159 \text { dyads of } \\
\text { oncology } \\
\text { outpatients and } \\
\text { primary care } \\
\text { givers } \\
\text { participated } \\
\text { (n }=318) . \\
\text { Carried out in } \\
\text { Taipei, Taiwan. } \\
\text { Not stratified }\end{array}$ & $\begin{array}{l}\text { To compare } \\
\text { attitudes on } \\
\text { barriers to pain } \\
\text { management } \\
\text { between } \\
\text { patients and } \\
\text { caregivers; to } \\
\text { discover if } \\
\text { barriers related } \\
\text { to hesitancy to } \\
\text { take analgesics; } \\
\text { to see if } \\
\text { attitudinal } \\
\text { barriers } \\
\text { predicted } \\
\text { adequacy of } \\
\text { analgesics used }\end{array}$ & $\begin{array}{l}\text { Concerns among both groups } \\
\text { about taking/ administering } \\
\text { analgesics (positively } \\
\text { correlated). Those with higher } \\
\text { levels of concern used } \\
\text { inadequate analgesics. Family } \\
\text { caregiver concerns were a } \\
\text { predictor of inadequate } \\
\text { management of cancer pain }\end{array}$ & $\begin{array}{l}\text { Research suggests } \\
\text { need for } \\
\text { educational } \\
\text { interventions to } \\
\text { encourage } \\
\text { optimal use of } \\
\text { analgesics to } \\
\text { ensure pain } \\
\text { management }\end{array}$ & $\begin{array}{l}\text { Local study. } \\
\text { Limitations } \\
\text { associated with } \\
\text { validity of } \\
\text { hesitancy (to } \\
\text { take analgesics) } \\
\text { measure. Study } \\
\text { only able to } \\
\text { demonstrate } \\
\text { associations } \\
\text { and causal } \\
\text { relationships }\end{array}$ & 19 \\
\hline $\begin{array}{l}\text { Lin, et al. } \\
\quad(2001)\end{array}$ & $\begin{array}{l}\text { Life-extending } \\
\text { therapies } \\
\text { among patients } \\
\text { with advanced } \\
\text { cancer: } \\
\text { patients' levels } \\
\text { of pain and } \\
\text { family } \\
\text { caregivers' } \\
\text { concerns about } \\
\text { pain relief }\end{array}$ & $\begin{array}{l}\text { Quasi- } \\
\text { experimental } \\
\text { study using } \\
\text { validated } \\
\text { questionnaire } \\
\text { surveys and } \\
\text { pain } \\
\text { inventories, to } \\
\text { assess } \\
\text { experience of } \\
\text { pain and } \\
\text { caregivers' } \\
\text { concerns }\end{array}$ & $\begin{array}{l}40 \text { pairs of patients } \\
\text { with advanced } \\
\text { cancer and their } \\
\text { caregivers } \\
(\mathrm{n}=80) \\
\text { recruited from } \\
\text { inpatient } \\
\text { oncology unit in } \\
\text { Taipei, Taiwan. } \\
52 \% \text { were } \\
\text { receiving } \\
\text { chemotherapy } \\
\text { or radiotherapy }\end{array}$ & $\begin{array}{l}\text { How prevalent is } \\
\text { use of life- } \\
\text { extending } \\
\text { therapies? Is } \\
\text { there a } \\
\text { relationship } \\
\text { between use of } \\
\text { therapies and } \\
\text { levels of pain? } \\
\text { Do caregivers } \\
\text { who patients } \\
\text { receive } \\
\text { therapies have } \\
\text { less concern } \\
\text { about pain } \\
\text { management } \\
\text { than those who } \\
\text { do not? Are } \\
\text { concerns } \\
\text { related to } \\
\text { hesitancy in } \\
\text { using } \\
\text { analgesics? }\end{array}$ & $\begin{array}{l}\text { Those who receiving therapies had } \\
\text { lower pain levels. All caregivers } \\
\text { had concerns about } \\
\text { administering analgesics and } \\
\text { reporting pain, but less the case } \\
\text { where receiving therapies. } \\
\text { Concerns about pain were } \\
\text { related to reluctance to report it }\end{array}$ & $\begin{array}{l}\text { Patients not } \\
\text { receiving } \\
\text { therapies may } \\
\text { have } \\
\text { inadequate pain } \\
\text { control. } \\
\text { Educational } \\
\text { interventions } \\
\text { concerning pain } \\
\text { management } \\
\text { required along } \\
\text { with } \\
\text { development of } \\
\text { palliative care }\end{array}$ & $\begin{array}{l}\text { Local study based } \\
\text { on relatively } \\
\text { small } \\
\text { convenience } \\
\text { sample of } \\
\text { patient- } \\
\text { caregiver dyads }\end{array}$ & 16 \\
\hline $\begin{array}{l}\text { Lin, et al. } \\
(2000)\end{array}$ & $\begin{array}{l}\text { Identifying } \\
\text { attitudinal } \\
\text { barriers to } \\
\text { family } \\
\text { management of }\end{array}$ & $\begin{array}{l}\text { A quasi- } \\
\text { experimental } \\
\text { study using } \\
\text { validated } \\
\text { questionnaire }\end{array}$ & $\begin{array}{l}80 \text { pairs of } \\
\text { palliative care } \\
\text { inpatients with } \\
\text { cancer and their } \\
\text { primary family }\end{array}$ & $\begin{array}{l}\text { Which attitudes } \\
\text { among family } \\
\text { caregivers } \\
\text { function as } \\
\text { barriers to pain }\end{array}$ & $\begin{array}{l}\text { Caregivers had concerns about } \\
\text { reporting pain and } \\
\text { administering analgesics in } \\
\text { relation to disease progression, } \\
\text { p.r.n. and possible side effects. }\end{array}$ & $\begin{array}{l}\text { Barriers to pain } \\
\text { management } \\
\text { exist among } \\
\text { informal } \\
\text { caregivers and }\end{array}$ & $\begin{array}{l}\text { Local study based } \\
\text { on modest } \\
\text { sample. Pain } \\
\text { Management } \\
\text { Index tool used }\end{array}$ & 18 \\
\hline
\end{tabular}


Table 1 (continued)

\begin{tabular}{|c|c|c|c|c|c|c|c|c|}
\hline $\begin{array}{l}\text { Author } \\
\text { and date }\end{array}$ & Article title & Design & Sample and setting & Research focus & Results/outcomes & Implications & Weaknesses & $\begin{array}{l}\text { Score } \\
(\max \\
32)\end{array}$ \\
\hline & $\begin{array}{l}\text { cancer pain in } \\
\text { palliative care } \\
\text { in Taiwan }\end{array}$ & $\begin{array}{l}\text { survey and pain } \\
\text { inventory tool } \\
\text { to investigate } \\
\text { barriers to pain } \\
\text { management. } \\
\text { Univariate and } \\
\text { bivariate } \\
\text { analysis }\end{array}$ & $\begin{array}{l}\text { caregivers } \\
(\mathrm{n}=160), \\
\text { recruited from } \\
\text { inpatient } \\
\text { palliative care } \\
\text { units in two } \\
\text { medical centres } \\
\text { in Taipei, Japan }\end{array}$ & $\begin{array}{l}\text { management? } \\
\text { How do barriers } \\
\text { impact on } \\
\text { hesitancy to } \\
\text { report pain and } \\
\text { administer } \\
\text { analgesics? } \\
\text { What is } \\
\text { relationship } \\
\text { between } \\
\text { attitudinal } \\
\text { barriers and } \\
\text { adequacy of } \\
\text { analgesics used } \\
\text { by patients }\end{array}$ & $\begin{array}{l}\text { Older and less educated } \\
\text { caregivers had stronger } \\
\text { concerns (barriers). Level of } \\
\text { caregiver concern related to } \\
\text { reluctance to administer } \\
\text { analgesics }\end{array}$ & $\begin{array}{l}\text { education } \\
\text { programme is } \\
\text { required to } \\
\text { address the } \\
\text { problem }\end{array}$ & $\begin{array}{l}\text { is questioned } \\
\text { by the authors }\end{array}$ & \\
\hline $\begin{array}{l}\text { Lin and Tsao } \\
\quad(2004)\end{array}$ & $\begin{array}{l}\text { Information needs } \\
\text { of family } \\
\text { caregivers of } \\
\text { terminal cancer } \\
\text { patients in } \\
\text { Taiwan }\end{array}$ & $\begin{array}{l}\text { Descriptive/ quasi- } \\
\text { experimental, } \\
\text { cross-sectional }\end{array}$ & $\begin{array}{l}90 \text { caregivers of } \\
\text { cancer patients } \\
\text { in hospice or } \\
\text { palliative unit, } \\
\text { Taiwan; using } \\
\text { two scales. } \\
\text { Measures: } \\
\text { demos, } \\
\text { information } \\
\text { needs and } \\
\text { experiences, } \\
\text { and attitude } \\
\text { scale. }\end{array}$ & & $\begin{array}{l}\text { Information needs in order: } \\
\text { patient's disease, caregiving, } \\
\text { palliative care, social welfare, } \\
\text { psychological issues and } \\
\text { spiritual care }\end{array}$ & $\begin{array}{l}\text { Providing } \\
\text { information } \\
\text { needs, using } \\
\text { the Information } \\
\text { Needs } \\
\text { Questionnaire } \\
\text { as a valid tool }\end{array}$ & $\begin{array}{l}\text { Potential for } \\
\text { redundancy in } \\
\text { measure. }\end{array}$ & 24 \\
\hline $\begin{array}{l}\text { Lobchuk and } \\
\text { Vorauer } \\
\text { (2003) }\end{array}$ & $\begin{array}{l}\text { Family caregiver } \\
\text { perspective- } \\
\text { taking and } \\
\text { accuracy in } \\
\text { estimating } \\
\text { cancer patient } \\
\text { symptom } \\
\text { experiences }\end{array}$ & $\begin{array}{l}\text { Descriptive, cross- } \\
\text { sectional } \\
\text { survey }\end{array}$ & $\begin{array}{l}80 \text { cancer patients } \\
\text { and } 80 \\
\text { caregivers (ie, } \\
\mathrm{n}=160 \text { ) } \\
\text { Hospice } \\
\text { inpatients in } \\
\text { Taiwan }\end{array}$ & $\begin{array}{l}\text { Caregivers } \\
\text { concerns about } \\
\text { analgesia as } \\
\text { barrier to } \\
\text { management of } \\
\text { pain }\end{array}$ & $\begin{array}{l}\text { Caregivers' estimates were closest } \\
\text { to patients' when asked to } \\
\text { imagine the patient's feelings }\end{array}$ & $\begin{array}{l}\text { Limited, technical } \\
\text { implications } \\
\text { only, but does } \\
\text { highlight the } \\
\text { technical } \\
\text { problems } \\
\text { involved in } \\
\text { using } \\
\text { caregivers as a } \\
\text { proxy for } \\
\text { patients }\end{array}$ & $\begin{array}{l}\text { Local study. } \\
\text { Sequencing of } \\
\text { different } \\
\text { reporting } \\
\text { exercises may } \\
\text { have biased } \\
\text { caregiver } \\
\text { perspective. } \\
\text { Limited } \\
\text { generalizability } \\
\text { of findings }\end{array}$ & 20 \\
\hline $\begin{array}{l}\text { Mazanec and } \\
\text { Bartel } \\
(2002)\end{array}$ & $\begin{array}{l}\text { Family caregiver } \\
\text { perspectives of } \\
\text { pain } \\
\text { management }\end{array}$ & $\begin{array}{l}\text { Descriptive, } \\
\text { qualitative: case } \\
\text { study analysis }\end{array}$ & $\begin{array}{l}\text { Case study of } \\
\text { female with } \\
\text { metastatic } \\
\text { cancer }\end{array}$ & $\begin{array}{l}\text { To illustrate the } \\
\text { experiences of } \\
\text { a caregiver in } \\
\text { the process of } \\
\text { pain } \\
\text { management } \\
\text { and identify } \\
\text { lessons to be } \\
\text { learned }\end{array}$ & $\begin{array}{l}\text { Education decrease the fear of } \\
\text { addiction in pain management }\end{array}$ & $\begin{array}{l}\text { Multi-disciplinary } \\
\text { work, } \\
\text { empowering } \\
\text { family } \\
\text { caregivers }\end{array}$ & $\begin{array}{l}\text { Single case study } \\
\text { design - } \\
\text { limitations in } \\
\text { generalizability }\end{array}$ & 9 \\
\hline $\begin{array}{l}\text { Milberg, et al. } \\
\quad(2003)\end{array}$ & $\begin{array}{l}\text { Advanced } \\
\text { palliative home } \\
\text { care: next- }\end{array}$ & $\begin{array}{l}\text { Qualitative, cross- } \\
\text { sectional study } \\
\text { using postal } \\
\text { questionnaire }\end{array}$ & $\begin{array}{l}217 \text { consecutive } \\
\text { bereaved } \\
\text { caregivers, } \\
\text { Sweden. Open }\end{array}$ & $\begin{array}{l}\text { To identify what } \\
\text { aspects of } \\
\text { advanced } \\
\text { palliative home }\end{array}$ & $\begin{array}{l}\text { Service aspects (staff, accessibility, } \\
\text { spectrum of services) and } \\
\text { comfort (feeling secure, being in } \\
\text { the centre, sharing caring, being }\end{array}$ & $\begin{array}{l}\text { Improving } \\
\text { caregivers- } \\
\text { professionals } \\
\text { communication }\end{array}$ & $\begin{array}{l}\text { Questionnaires } \\
\text { distributed up } \\
\text { to seven } \\
\text { months post }\end{array}$ & 24 \\
\hline
\end{tabular}


Table 1 (continued)

\begin{tabular}{|c|c|c|c|c|c|c|c|c|}
\hline $\begin{array}{l}\text { Author } \\
\text { and date }\end{array}$ & Article title & Design & Sample and setting & Research focus & Results/outcomes & Implications & Weaknesses & $\begin{array}{l}\text { Score } \\
(\max \\
32)\end{array}$ \\
\hline & $\begin{array}{l}\text { of-kin's } \\
\text { perspective }\end{array}$ & & $\begin{array}{l}\text { ended } \\
\text { questionnaire }\end{array}$ & $\begin{array}{l}\text { care are } \\
\text { important to } \\
\text { next of kin }\end{array}$ & $\begin{array}{l}\text { at home). Positive staff-related } \\
\text { comments (continuity, } \\
\text { reliability, competence, sharing } \\
\text { of care and recognition of } \\
\text { patient and next of kin wishes, } \\
\text { expertise, attitude and } \\
\text { communication). Positive } \\
\text { service-related comments (24- } \\
\text { hour accessibility, making it } \\
\text { possible to remain at home) }\end{array}$ & & $\begin{array}{l}\text { death, creating } \\
\text { potential recall } \\
\text { bias }\end{array}$ & \\
\hline $\begin{array}{r}\text { Seamark, et } \\
\text { al. (1998) }\end{array}$ & $\begin{array}{l}\text { Dying from cancer } \\
\text { in community } \\
\text { hospitals or a } \\
\text { hospice: closest } \\
\text { lay carers' } \\
\text { perceptions }\end{array}$ & $\begin{array}{l}\text { Quasi- } \\
\text { experimental } \\
\text { retrospective } \\
\text { study using } \\
\text { structured } \\
\text { interview or } \\
\text { questionnaire } \\
\text { to compare } \\
\text { quality of } \\
\text { terminal cancer } \\
\text { care in } \\
\text { community } \\
\text { hospital with } \\
\text { that in a } \\
\text { hospice. } \\
\text { Univariate and } \\
\text { bivariate } \\
\text { analysis }\end{array}$ & $\begin{array}{l}91 \text { caregivers } \\
\text { whose patient } \\
\text { had died in } \\
\text { community } \\
\text { hospital and } 70 \\
\text { who had died in } \\
\text { a hospice (ie, } \\
n=161 \text { ) in East } \\
\text { Devon/Exeter, } \\
\text { UK }\end{array}$ & $\begin{array}{l}\text { Investigation of } \\
\text { quality of } \\
\text { service } \\
\text { provided by } \\
\text { community } \\
\text { hospitals in } \\
\text { comparison to } \\
\text { hospices } \\
\text { (derived from } \\
\text { views of } \\
\text { informal } \\
\text { caregivers) }\end{array}$ & $\begin{array}{l}\text { Caregivers rated hospice care as } \\
\text { excellent; } 40 \% \text { suggested } \\
\text { improvements possible in } \\
\text { community hospitals. Key } \\
\text { criticisms of latter: } \\
\text { communication problems, lack } \\
\text { of nursing staff, lack of } \\
\text { bereavement support. } \\
\text { Caregivers of patients in } \\
\text { hospices, more likely to be } \\
\text { present at time of death }\end{array}$ & $\begin{array}{l}\text { Potential for } \\
\text { making } \\
\text { improvements } \\
\text { in community } \\
\text { hospitals in } \\
\text { terms of } \\
\text { communication } \\
\text { skills of } \\
\text { professionals, } \\
\text { more } \\
\text { professional } \\
\text { training in end } \\
\text { of life care and } \\
\text { bereavement }\end{array}$ & $\begin{array}{l}\text { Local, single site } \\
\text { study with } \\
\text { limited } \\
\text { generalizability. } \\
\text { Analysis of data } \\
\text { derived from } \\
\text { different } \\
\text { methods: } \\
\text { interview vs } \\
\text { questionnaire }\end{array}$ & 21 \\
\hline Spruyt (1999) & $\begin{array}{l}\text { Community-based } \\
\text { palliative care } \\
\text { for Bangladeshi } \\
\text { patients in east } \\
\text { London. } \\
\text { Accounts of } \\
\text { bereaved carers }\end{array}$ & $\begin{array}{l}\text { Descriptive, } \\
\text { qualitative, } \\
\text { retrospective }\end{array}$ & $\begin{array}{l}18 \text { interviews with } \\
\text { ethnic minority } \\
\text { caregivers, } \\
\text { London. Range: } \\
\text { death to } \\
\text { interview } \\
=16-96 \\
\text { months; } \\
\text { translators used }\end{array}$ & & $\begin{array}{l}\text { Findings about communication in } \\
\text { the last days, symptom control, } \\
\text { preparation for death, spiritual } \\
\text { care, impact on caregivers, } \\
\text { bereavement, social services. } \\
\text { High levels of spiritual care } \\
\text { throughout, variation in } \\
\text { translation ability in line with } \\
\text { family member ability to speak } \\
\text { English (often left children with } \\
\text { burden), mixed views on } \\
\text { whether patient should be told } \\
\text { prognosis. HP team viewed } \\
\text { positively. Preference for burial } \\
\text { abroad created financial strain }\end{array}$ & $\begin{array}{l}\text { Provision of care } \\
\text { for Bangladeshi } \\
\text { community. } \\
\text { Need for } \\
\text { palliative care } \\
\text { team } \\
\text { awareness of } \\
\text { social dynamics } \\
\text { and traditional } \\
\text { values. Must } \\
\text { recognize } \\
\text { preference for } \\
\text { homeland } \\
\text { burial }\end{array}$ & $\begin{array}{l}\text { Not fully taped and } \\
\text { transcribed. } \\
\text { Interview was } \\
\text { member of } \\
\text { community- } \\
\text { professional } \\
\text { interpreter in } \\
\text { only } 4 \text { cases }\end{array}$ & 20 \\
\hline $\begin{array}{l}\text { Terry, et al. } \\
\quad(2006)\end{array}$ & $\begin{array}{l}\text { Experience of } \\
\text { dying: concerns } \\
\text { of dying } \\
\text { patients and of } \\
\text { carers }\end{array}$ & $\begin{array}{l}\text { Qualitative, } \\
\text { interview and } \\
\text { focus group } \\
\text { based study }\end{array}$ & $\begin{array}{l}36 \text { hospice } \\
\text { patients, } 18 \\
\text { caregivers of } \\
\text { patients within } \\
\text { the palliative } \\
\text { care service } \\
\text { (retrospective } \\
\text { experiences - } \\
\text { patient died }\end{array}$ & $\begin{array}{l}\text { Comparison of } \\
\text { patient and } \\
\text { caregiver } \\
\text { reflections on } \\
\text { process of care } \\
\text { with particular } \\
\text { regard to; } \\
\text { physical and } \\
\text { emotional }\end{array}$ & $\begin{array}{l}\text { Privacy and Autonomy: patients } \\
\text { highlighted their preference to } \\
\text { censor information prior to } \\
\text { sharing it with families/ } \\
\text { caregivers. Caregivers believed } \\
\text { that they should be provided } \\
\text { with complete information } \\
\text { about the patients illness, even } \\
\text { when the patient explicitly }\end{array}$ & $\begin{array}{l}\text { Highlighted the } \\
\text { need for } \\
\text { information } \\
\text { regarding } \\
\text { patient and } \\
\text { caregiver views } \\
\text { on } \\
\text { confidentiality } \\
\text { of info to be }\end{array}$ & Small sample & 23 \\
\hline
\end{tabular}


Table 1 (continued)

\begin{tabular}{|c|c|c|c|c|c|c|c|c|}
\hline $\begin{array}{l}\text { Author } \\
\text { and date }\end{array}$ & Article title & Design & Sample and setting & Research focus & Results/outcomes & Implications & Weaknesses & $\begin{array}{l}\text { Score } \\
\text { (max } \\
32) \\
\end{array}$ \\
\hline & & & $\begin{array}{l}\text { between six } \\
\text { months and } \\
\text { four years } \\
\text { previously). } \\
\text { Australia }\end{array}$ & $\begin{array}{l}\text { concerns, } \\
\text { information and } \\
\text { decision } \\
\text { making. }\end{array}$ & $\begin{array}{l}\text { refused to share the info with } \\
\text { them. Caregivers also had } \\
\text { detailed and practical concerns } \\
\text { about medication; timing, } \\
\text { dosage, titration with symptoms }\end{array}$ & $\begin{array}{l}\text { gathered to } \\
\text { ensure patient } \\
\text { and caregiver } \\
\text { needs were } \\
\text { met. Multiple } \\
\text { actions are } \\
\text { outlined with } \\
\text { regards to the } \\
\text { improvement in } \\
\text { info provision } \\
\text { at key stages in } \\
\text { the patient } \\
\text { trajectory in } \\
\text { particular prior } \\
\text { to death }\end{array}$ & & \\
\hline $\begin{array}{l}\text { Waldrop, et } \\
\quad \text { al. (2005) }\end{array}$ & $\begin{array}{l}\text { Final transitions: } \\
\text { Family } \\
\text { caregiving at } \\
\text { the end of life }\end{array}$ & $\begin{array}{l}\text { Qualitative study } \\
\text { using semi- } \\
\text { structured in- } \\
\text { depth } \\
\text { interviews }\end{array}$ & $\begin{array}{l}74 \text { caregivers of } \\
\text { patients in } \\
\text { terminal stage } \\
\text { of illness with } \\
\text { cancer. USA }\end{array}$ & $\begin{array}{l}\text { Exploration of end } \\
\text { stage care } \\
\text { giving, in } \\
\text { particular needs } \\
\text { associated with } \\
\text { transition }\end{array}$ & $\begin{array}{l}\text { Quality of interaction between } \\
\text { caregiver and physicians was } \\
\text { highly variable particularly in } \\
\text { terms of the extent to which } \\
\text { they explained the details of the } \\
\text { situation. Caregivers functioned } \\
\text { as the executive for the patient } \\
\text { and therefore negotiated } \\
\text { assistance for the patient, } \\
\text { facilitated secondary support, } \\
\text { interpreted info etc. Caregivers } \\
\text { face practical problems } \\
\text { including maintaining } \\
\text { employment and dealing with } \\
\text { financial concerns }\end{array}$ & $\begin{array}{l}\text { All professionals } \\
\text { should carry } \\
\text { out an initial } \\
\text { assessment of } \\
\text { the caregiver's } \\
\text { perspective and } \\
\text { what level of } \\
\text { information } \\
\text { they desire }\end{array}$ & $\begin{array}{l}\text { Limited to hospice } \\
\text { care, reduces } \\
\text { transferability } \\
\text { to other } \\
\text { populations. } \\
\text { Small } \\
\text { percentage of } \\
\text { ethnically } \\
\text { diverse } \\
\text { caregivers } \\
\text { limits the } \\
\text { conclusions } \\
\text { that can be } \\
\text { drawn } \\
\text { regarding } \\
\text { cultural } \\
\text { variation and } \\
\text { applicability }\end{array}$ & 25 \\
\hline $\begin{array}{c}\text { Ward, et al. } \\
\quad(1996)\end{array}$ & $\begin{array}{l}\text { Concerns about } \\
\text { analgesics } \\
\text { among patients } \\
\text { and family } \\
\text { caregivers in a } \\
\text { hospice setting }\end{array}$ & $\begin{array}{l}\text { Quasi- } \\
\text { experimental } \\
\text { study } \\
\text { comparing } \\
\text { patient and } \\
\text { family } \\
\text { caregivers } \\
\text { concerns about } \\
\text { analgesics. } \\
\text { Used validated } \\
\text { questionnaire } \\
\text { to measure } \\
\text { concern - } \\
\text { 'Barriers } \\
\text { Questionnaire'. } \\
\text { Includes } \\
\text { univariate and } \\
\text { bivariate } \\
\text { analysis }\end{array}$ & $\begin{array}{l}35 \text { dyads of } \\
\text { patients and } \\
\text { caregivers (ie, } \\
\mathrm{n}=70 \text { ) } \\
\text { attending } \\
\text { hospice at } \\
\text { home } \\
\text { programmes in } \\
\text { Mid West and } \\
\text { East Coast USA }\end{array}$ & $\begin{array}{l}\text { To compare patient } \\
\text { and caregiver } \\
\text { concerns about } \\
\text { the use of } \\
\text { analgesics (eg, } \\
\text { fear of } \\
\text { addiction, } \\
\text { worry about } \\
\text { tolerance, } \\
\text { worry about } \\
\text { side effects) }\end{array}$ & $\begin{array}{l}\text { There was no correlation between } \\
\text { patients' concerns and } \\
\text { caregivers concerns, suggesting } \\
\text { that one member of the dyad } \\
\text { has greater concerns than the } \\
\text { other }\end{array}$ & $\begin{array}{l}\text { Critical that } \\
\text { clinicians } \\
\text { attend to both } \\
\text { patients and } \\
\text { caregiver with } \\
\text { respect to } \\
\text { assessment, } \\
\text { and } \\
\text { intervention. } \\
\text { Further } \\
\text { research } \\
\text { needed to see } \\
\text { how concerns } \\
\text { change over the } \\
\text { duration of the } \\
\text { illness }\end{array}$ & $\begin{array}{l}\text { Relatively small, } \\
\text { homogenous } \\
\text { sample. } \\
\text { Patients and } \\
\text { caregivers in } \\
\text { more advanced } \\
\text { stage of illness } \\
\text { may have } \\
\text { under- } \\
\text { represented. } \\
\text { Reliability of } \\
\text { some of Barrier } \\
\text { Questionnaire } \\
\text { scores low }\end{array}$ & 23 \\
\hline
\end{tabular}


$17,24,25$ Research was undertaken in a variety of settings including: patients' homes, hospices, outpatient oncology clinics, community hospitals and in other community institutions. Studies were carried out in a wide range of

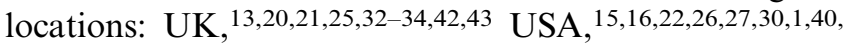
45,46 Taiwan, ${ }^{35-38}$ Canada, ${ }^{17,18,24,39}$ Australia, ${ }^{14,19,28,44}$ Japan, ${ }^{23}$ the Netherlands ${ }^{29}$ and Sweden. ${ }^{41}$ Twenty-four papers dealt solely with cancer, while the remaining 10 included patients with a range of conditions as well as cancer, including cardio-respiratory illness, circulatory disease, renal failure, chronic obstructive pulmonary disease (COPD) and dementia. ${ }^{13,15,18,20,21,25,27,33,41,44}$

\section{Critical appraisal of included studies}

The majority of studies deployed a descriptive cohort design; 13 used questionnaires/surveys (the majority including non-validated scales), nine used interviews/ focus groups and an additional five used both methods. In addition, three studies utilized a descriptive comparative design (comparing either an intervention with a control or comparison of a patient and a caregiver). A further three studies used an exploratory grounded theory approach (interview based) and another adopted a case study methodology. Associated weaknesses included: poor generalizability, opportunistic sampling, frequent use of non-validated instruments, high potential for confounding due to descriptive nature of studies, limited information on causal relationships, and response and recall bias. A summary of sample sizes and critical appraisal framework scores is presented in Table 2.

\section{Outcomes of included studies}

Caregivers reported multiple concerns and areas of inadequate knowledge in relation to pain management including understanding of side effects, disease progression, addiction and tolerance. ${ }^{14,35-37}$ Concerns were greatest among older caregivers and those with less education. ${ }^{16,37}$ Poor correlation was reported between caregiver and patient concerns regarding pain management. ${ }^{46}$ Confusion around medication use focused in particular upon uncertainty in the caregiver role and practical concerns regarding timing of administration, dosage and titration of dosage to treat increasing symptoms. ${ }^{30,44}$ Life-extending therapies and increased education were found to improve pain management via such outcomes as decreased caregiver fear of

Table 2 Critical appraisal framework scores and study sample sizes

\begin{tabular}{ll} 
Mean appraisal score (out of possible 32) & 20 \\
Range (appraisal score) & $9-25$ \\
Sample size $\leq 50$ & 11 \\
Sample size $>50$ but $\leq 100$ & 14 \\
Sample size $>100$ & 9 \\
\hline
\end{tabular}

addiction. ${ }^{36,40}$ Ongoing health professional evaluation of medicine use and increased verbal and written information in line with caregiver need were found to enhance understanding. ${ }^{30}$ In response, recommendations highlighted the value of a multi-disciplinary approach to care with a particular focus upon increased education to improve understanding and empower caregivers. ${ }^{14,30,35-37,40}$ Caregiver self-efficacy regarding symptom control was significantly increased following caregiver-guided pain management training via nurse-led home visits, although no significant change in treatment effects for patients was reported. ${ }^{31}$ In addition, studies suggest that staff must attempt to understand the varying perspectives of caregivers and attend to both caregiver and patient information needs in pain management. ${ }^{16,46}$

Studies reported variation in patient and caregiver consensus with regard to a range of issues, including: perceptions of physical and psychological symptoms; patient distress and their experience of pain; level of home support required and satisfaction with physician trust; clarity of information and listening skills, with the caregiver often displaying higher levels of dissatisfaction with regards to the latter. ${ }^{21,22,27,39}$ Caregiver-patient discourse was characterized by a range of themes including denial, second guessing, previous communication styles, illness-related dialogue and bereavement. ${ }^{15}$ Consensus was also limited with regards to views on information dissemination. Views ranged from the need for a basic level of consistent information between both parties to facilitate an accurate and shared expectation of the future (with caregiver access to additional information only when patient permission was granted), to caregiver preference for full access to information without patient censoring as recognition of their caregiving role. ${ }^{19,44}$ In response, studies suggest staff need to be aware of potential changes in caregiverpatient discourse in line with factors like disease progression and differences in preference regarding ownership of information. ${ }^{15,19,44}$ In addition, caregivers were found to be more accurate in estimating patient experience when encouraged to imagine the patient's feelings. ${ }^{39}$

Communication between caregivers and health professionals was a key issue in determining the adequacy of information provision and caregiver understanding. Quality of communication was found to be variable, particularly in relation to the level of detail of the information provided; this could result in poor caregiver knowledge and understanding. ${ }^{13,45}$ It was found that caregivers frequently sought a personalized relationship with health professional as a means to facilitating staff understanding of their needs, including the need to talk freely about the disease and feel comfortable in raising difficult issues. ${ }^{18,29}$ Deficiencies in communication related in particular to inadequacies in the amount of time given for discussion and the number of meetings between the caregiver and health professional. Where these deficiencies were met, 
caregivers experienced increased reassurance, knowledge and an enhanced sense of control. ${ }^{18}$ In response, health professionals should facilitate a proactive caregiver approach by offering opportunities for communication. ${ }^{18}$ In addition, all health professionals should carry out an initial assessment of the caregiver perspective and the level of information desired. ${ }^{45}$

Information needs were reported to be a key component of caregiver coping strategies. ${ }^{26,29}$ Studies identified disease-related information, including information that led to understanding of events that might indicate disease progression and death as the primary preference, followed by information relating to palliative care, social welfare, psychological issues and spiritual care. ${ }^{23,38,44}$ One study identified inadequate information provision to be a weakness of community palliative care. ${ }^{34}$ Access to highquality information was associated with a decrease in anxiety due to enhanced perception of control. ${ }^{32}$ Recommendations included the provision of information to meet the individual needs of caregivers in line with concerns and disease progression and the provision of information on community agencies. ${ }^{34,38}$ In addition, information assessment instruments and support programmes should be developed to respond to caregiver information and communication needs. ${ }^{26,29,38}$

Specific groups of palliative care patients were found to experience particular dissatisfaction with services. Noncancer patients (cardio-respiratory) were found to experience greater inadequacies in information provision and Black Caribbean patients expressed dissatisfaction with health professional communication and information provision. ${ }^{20,33}$ In contrast, a study focusing on the experience of Bangladeshi patients who received community based palliative care, reported considerable satisfaction with health professional communication, although there were difficulties with translation where family members were involved. ${ }^{43}$ Where family, as opposed to professional interpreters, have been used, this has generated concerns regarding the power of individuals to withhold information. ${ }^{19}$ The article additionally highlighted the importance of understanding social dynamics and traditional values, including burial preferences and spiritual needs, in providing appropriate palliative care. ${ }^{43}$ Positive experiences of health professional interaction were associated with good communication. ${ }^{41}$ Negative experiences, as observed in one study of community hospitals, was associated with poor communication. ${ }^{42}$ In general, recommendations focused upon the need for improvement in health professional communication skills, ${ }^{41,42}$ the value of improved staff recognition of the varying needs of patients and caregivers in accordance with ethnicity, ${ }^{33,43}$ and the value of increased staff training in the principles of inclusive palliative care. ${ }^{33}$

Four studies focused upon either the implementation or development of an intervention for caregivers in palliative care. Interventions included: a tool for defining and solving problems; identification of obstacles to effective care and subsequent adjustments; psycho-educational support to improve caregiver knowledge of delirium; a 90-minute group of informal multi-professional teaching and peer support; and a nursing intervention combining guidance and support. ${ }^{17,24,25,28}$ Although a key focus of each intervention was to increase knowledge generally through the provision of education and information, weaknesses in method made it difficult to establish impact (there was typically no control group, and limited controlling of confounders) or generalizability (often, studies related to a single site). ${ }^{17,25,28}$ Recommendations focused on the need for future rigorous evaluations of interventions. ${ }^{25}$

\section{Discussion}

A central goal of palliative care is the appropriate management of pain. This was strongly reflected in the evidence reviewed where a substantial number of papers examined the multiple barriers to pain management among informal caregivers and patients, frequently emphasizing inadequate knowledge, poor communication and lack of patient-caregiver consensus. As Ward, et al. have observed, 'these findings highlight the need for patient and caregiver education about reporting pain and using analgesics'. ${ }^{46}$ Although educational and multidisciplinary approaches to targeting such barriers were outlined, these were small in number, limited to specific settings and weakly evaluated. Other caregiver information needs were also identified, such as knowledge of social welfare provision and spiritual support, but these were rarely addressed by professionals involved in the delivery of end of life care. This gap was additionally reflected in information assessment with limited development of caregiver-specific assessment tools.

The provision of information and support to caregivers has also been shown to vary according to patient disease type and ethnicity, creating inequities in care and barriers to the development of inclusive palliative care. Indeed it has been argued that certain minority ethnic groups 'will strongly favour home deaths because of the isolation in hospitals from poor communication, the differing food requirements and the desire to observe religious duties' ${ }^{43}$ This tendency, along with the compounding issue of socio-economic disadvantage faced by some minority ethnic communities, underlines the need to cater for the cultural diversity of caregiver needs. Although a small number of interventions responding to inadequacies in caregiver knowledge were identified, these were poorly designed and inadequately evaluated, offering limited recommendations.

The evidence base for understanding caregivers' knowledge and information needs in palliative care is 
therefore limited. It is also disparate, in terms of topics covered, study design, outcomes and generalizability (in particular locally based studies). Methodologically, the evidence base is predominantly descriptive, based on small-scale studies and therefore frequently outside of the standard hierarchies of evaluation in medical research. There are few quantitative studies and no randomized controlled trials or controlled experimental designs, although there are particular concerns over conducting such trials in palliative settings. ${ }^{47}$ Consequently, no study was able to determine causality in a statistically credible manner. Although a number of papers combined a qualitative and quantitative approach, triangulation of findings was limited. Sample sizes were generally small and in cases of repeated measurement, attrition rates were high, although this did not prevent some studies using inappropriate analytical techniques. A variety of validated and non-validated assessment tools were used creating difficulties with comparison. These combined factors significantly limit generalizability. However, this limitation was not fully recognized in the conclusions of some studies, where there was a tendency to apply findings to situations beyond the scope of the study.

However, there are also a number of strengths to the evidence base, which in many ways reflect the richness and diversity of approach characteristic of palliative care. The descriptive nature of findings offers an indepth understanding of caregiver knowledge and information needs. The evidence base also embraces the diversity of palliative care settings and therefore the variation of associated caregiver needs. Although the methodological approach is weak when judged against standard medical research criteria, researchers in the field have been successful in developing techniques that reflect the sensitivity of end of life care, offering other medical specialisms examples of where a qualitative approach could be beneficial in understanding health care needs and experiences.

\section{Conclusion and implications}

Future research must address the weaknesses identified in the current review. As Irene Higginson has recently argued in relation to clinical research in palliative care, it would be nice to have a larger and more rigorously researched evidence base. ${ }^{48}$ In relation to the focus of this review, a greater level of triangulation is required both within and between studies, which consider the needs of caregivers. Given the predominance of qualitative research in the field, further steps must be taken to enhance rigour, including triangulation through the use of multiple data sources, reflexivity, attention to negative cases and greater consistency in approaches to external and internal validity. ${ }^{49}$
Methodologically and conceptually, research in this field is dyad focused, frequently examining the relationships between two agents in the palliative care setting: patient-caregiver, patient-professional or professionalcaregiver. This contrasts with the practice of palliative care itself, which is founded upon the idea of a holistic approach, ${ }^{50}$ supporting an ongoing interaction and dialogue between the triad of patient, caregiver and service provider. The available evidence therefore suggests a discrepancy between the practice and overall philosophy of palliative care and the research methodologies used to study it, as illustrated in Figure 1. As care moves into patients' homes, where such three-way interactions will be a core feature of the practice of palliative medicine, it is important that researchers design studies that can adequately capture the complex dynamics of this situation. Without employing this more holistic approach, it is likely that the knowledge and information needs of informal caregivers will not be fully understood.

Alongside this conceptual omission, a number of significant gaps can be identified in the evidence base relevant to developing policy and practice. The majority of papers were concerned with the knowledge and information needs of caregivers of patients with cancer. As palliative care broadens to meet the needs of patients with other life-threatening conditions, it is necessary to undertake research to understand the experiences of these caregivers. Additionally, there were only a limited range of studies that sought to understand the dynamics of caring among

Current dyad approach

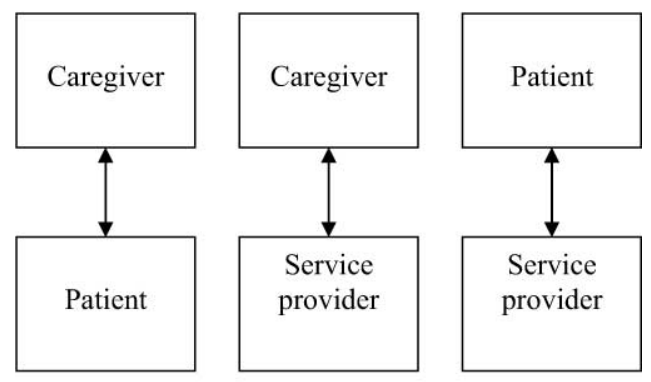

Holistic triad approach

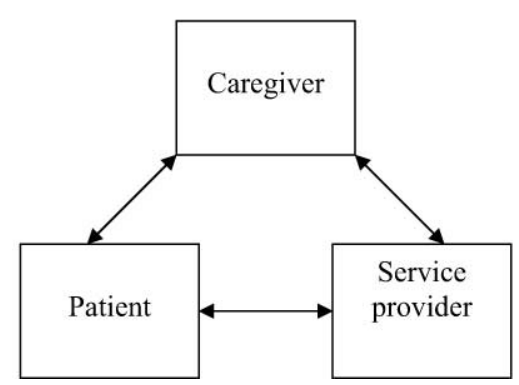

Figure 1 Dyad and holistic approaches to research design in palliative care. 
minority ethnic people, where the interactions of culture, belief and palliative care may alter the patterns of caregiver need. This points to the importance of understanding the needs of all caregivers that are not directly related to the medical condition of the patient such as spirituality, social well being, finance and work-related needs. These factors should be incorporated within wider professional assessment of caregiver needs and be considered alongside more medicalized requirements such as knowledge of pain management. Finally, research, policy and practice must reflect the often complex and fast-paced changes to caregivers' roles and information needs associated with disease progression. ${ }^{51}$ Service providers must incorporate all of the above within professional training to allow for caregiver needs to be appropriately matched to professional skills.

It is clear from this review that there are many issues that need to be addressed in order to provide an effective, efficient and responsive palliative care service, which meets the needs of all individuals involved in the triad of care. If the current policy in the UK of developing the provision of home-based palliative care is to be successful, we need to better understand the roles and needs of informal caregivers through:

- an improved evidence base utilizing a variety of appropriate methodological approaches deploying consistency in research design and evaluation;

- greater recognition of dynamics of care, including the patient-caregiver-professional triad and the implications of disease progression;

- increased focus upon, and rigorous evaluation of, caregiver specific knowledge-related interventions and needs assessment tools;

- enhanced training for those providing services to improve communication skills, develop cultural competence, improve understanding of non-cancer conditions and the non-medicalized needs of caregivers.

\section{Contribution}

$\mathrm{AD}, \mathrm{AO}, \mathrm{MAL}$ and RP undertook the search and review. $\mathrm{AD}, \mathrm{AO}$ and MAL drafted the article. YHC, RP and JW commented on, contributed to and edited subsequent drafts. The study of which this article forms a part is codirected by YHC and RP; JW is the Senior Researcher. $\mathrm{YHC}$ is the guarantor of the paper.

\section{Ethical approval}

Not required.

\section{Acknowledgements}

This review is part of a wider project evaluating the UK Big Lottery Fund's Palliative Care Initiative. We would like to gratefully acknowledge the support of the Big Lottery Fund. Financial assistance was also generously provided by a small grant from Warwick Medical School. The researchers are independent of these funders.

\section{References}

1 Marie Curie Cancer Care. Marie Curie Cancer Care Launches 'Supporting the Choice to Die at Home' campaign, 2004. http://www.mariecurie.org.uk/aboutus/news/ news_archive/news_archive_2004/marie_curie_cancer_ care+launches_supporting_the_choice_to_die_at_home_ campaign.htm (site accessed 8 June 2007).

2 BMJ. 'What is your idea of a good death? Results of an on-line survey', 2003. http://bmj.bmjjournals.com/misc/ good_death.shtml (site accessed 9 May 2005)

3 Higginson, IJ, Sen-Gupta, GJA. Place of care in advanced cancer: a qualitative systematic literature review of patient preferences. J Palliat Med 2000; 3: 287-300.

4 Ellershaw, J, Ward, C. Care of the dying patient: the last hours or days of life. BMJ 2003; 326: 30-34.

5 House of Commons; Health Committee. Palliative Care. Fourth Report of Session 2003-04. London: House of Commons, 2004.

6 Higginson, IJ, Finlay, IG, Goodwin, DM, et al. Is there evidence that palliative care teams alter end-of-life experiences of patients and their caregivers? J Pain Symptom Manage 2003; 25: 150-168.

7 Taylor, D, Carter, S. Valuing Choice-Dying at Home: A Case for the More Equitable Provision of High Quality Support for People who Wish to Die at Home. An Economic and Social Policy Opinion Commissioned by Marie Curie Cancer Care. London: Marie Curie Cancer Care, 2004.

8 Gomes, B, Higginson, IJ. Factors influencing death at home in terminally ill patients with cancer: systematic review. BMJ 2006; 332: 515-518.

9 Harding, R, Higginson, IJ. What is the best way to help caregivers in cancer and palliative care? A systematic literature review of interventions and their effectiveness. Palliat Med 2003; 17: 63-74.

10 Hudson, P. A critical review of supportive interventions for family caregivers of patients with palliative-stage cancer. J Psychosocial Oncology 2003; 22: 77-92.

11 Hughes, PM, Ingleton, MC, Noble, B, Clark, D. Providing cancer and palliative care in rural areas: a review of patient and caregiver needs. J Palliat Care 2004; 20: 44 49.

12 Hawker, S, Payne, S, Kerr, C, Hardey, M, Powell, J. Appraising the evidence: reviewing disparate data systematically. Qual Health Res 2002; 12: 1284-1299. 
13 Aldred, H, Gott, M, Gariballa, S. Advanced heart failure: impact on older patients and informal carers. Journal of Advanced Nursing 2005; 49: 116-124.

14 Aranda, S, Yates, P, Edwards, H, Nash, R, Skerman, H, McCarthy, A. Barriers to effective cancer pain management: a survey of Australian family caregivers. Eur $J$ Cancer Care (Engl) 2004; 13: 336-343.

15 Beach, DL. Caregiver discourse: perceptions of illnessrelated dialogue. Hosp $J$ 1995; 10: 13-25.

16 Berry, P-E, Ward, S-E. Barriers to pain management in hospice: a study of family caregivers. Hosp J 1995; 10: 19.

17 Cameron, JI, Shin, JL, Williams, D, Stewart, DE. A brief problem-solving intervention for family caregivers to individuals with advanced cancer. J Psychosom Res 2004; 57: 137-143.

18 Caron, C, Griffith, D, Arcand, M. Decision making at the end of life in dementia: how family caregivers perceive their interactions with health care providers in long term care settings. Journal of Applied Gerontology 2005; 24: 231-247.

19 Clayton, J, Butow, P, Tattersal, M. The needs of terminally ill cancer patients versus those of caregivers for information regarding prognosis and end of life issues. Cancer 2005; 103: 1957-1964.

20 Exley, C, Field, D, Jones, L, Stokes, T. Palliative care in the community for cancer and end-stage cardiorespiratory disease: the views of patients, lay-caregivers and health care professionals. Palliat Med 2005; 19: 76-83.

21 Field, D, Douglas, C, Jagger, C, Dand, P. Terminal illness: views of patients and their lay caregivers. Palliat Med 1995; 9: 45-54.

22 Fine, PG, Busch, MA. Characterization of breakthrough pain by hospice patients and their caregivers. J Pain Symptom Manage 1998; 16: 179-183.

23 Fukui, S. Information needs and the related variables of Japanese family caregivers of terminally ill cancer patients. Nurs Health Sci 2004; 6: 29-36.

24 Gagnon, P, Charbonneau, C, Allard, P, Soulard, C, Dumont, S, Fillion, L. Delirium in advanced cancer: a psychoeducational intervention for family caregivers. $J$ Palliat Care 2002; 18: 253-261.

25 Harding, R, Higginson, IJ, Leam, C, et al. Evaluation of a short-term group intervention for informal caregivers of patients attending a home palliative care service. J Pain Symptom Manage 2004; 27: 396-408.

26 Harrington, V, Lackey, NR, Gates, MF. Needs of caregivers of clinic and hospice cancer patients. Cancer Nurs 1996; 19: 118-125.

27 Hauser, J, Chih-Hung, C, Alpert, H, Baldwin, D, Emanuel, E, Emanuel, L. Who's caring for whom? Differing perspectives between seriously ill patients and their family caregivers. Am J Hospice Palliat Med 2006; 23: 105-112.

28 Hudson, P, Aranda, S, McMurray, N. Intervention development for enhanced lay palliative caregiver support - the use of focus groups. Eur $J$ Cancer Care (Engl) 2002; 11: 262-270.
29 Jansma, FF, Schure, LM, de Jong, BM. Support requirements for caregivers of patients with palliative cancer. Patient Educ Couns 2005; 58: 182-126.

30 Kasanowski, M. Commitment to the end: family caregivers medication management of symptoms in patients with cancer near death. Dissertation, Boston, MA, 1998.

31 Keefe, F, Ahles, T, Sulton, L, et al. Partner guided cancer pain management at the end of life: a preliminary study. $J$ Pain Symptom Manage 2005; 29: 263-272.

32 Kessler, D, Peters, T, Lee, L, Parr, S. Social class and access to specialist palliative care services. Palliat Med 2005; 19: 105-110.

33 Koffman, J, Higginson, IJ. Accounts of caregivers' satisfaction with health care at the end of life: a comparison of first generation black Caribbeans and white patients with advanced disease. Palliat Med 2001; 15: 337-345.

34 Lecouturier, J, Jacoby, A, Bradshaw, C, Lovel, T, Eccles, M. Lay caregivers' satisfaction with community palliative care: results of a postal survey. South Tyneside MAAG Palliative Care Study Group. Palliat Med 1999; 13: $275-283$.

35 Lin, CC. Barriers to the analgesic management of cancer pain: a comparison of attitudes of Taiwanese patients and their family caregivers. Pain 2000; 88: 7-14.

36 Lin, CC, Lai, YL, Lo, EC. Life-extending therapies among patients with advanced cancer: patients' levels of pain and family caregivers' concerns about pain relief. Cancer Nurs 2001; 24: 430-435.

37 Lin, CC, Wang, P, Lai, YL, Lin, CL, Tsai, SL, Chen, TT. Identifying attitudinal barriers to family management of cancer pain in palliative care in Taiwan. Palliat Med 2000; 14: 463-470.

38 Lin, WC, Tsao, CJ. Information needs of family caregivers of terminal cancer patients in Taiwan. Am J Hosp Palliat Care 2004; 21: 438-444.

39 Lobchuk, MM, Vorauer, JD. Family caregiver perspective-taking and accuracy in estimating cancer patient symptom experiences. Soc Sci Med 2003; 57: 2379-2384.

40 Mazanec, P, Bartel, J. Family caregiver perspectives of pain management. Cancer Pract 2002; 10 Suppl 1: S66S69.

41 Milberg, A, Strang, P, Carlsson, M, Borjesson, S. Advanced palliative home care: next-of-kin's perspective. J Palliat Med 2003; 6: 749-756.

42 Seamark, DA, Williams, S, Hall, M, Lawrence, CJ, Gilbert, J. Dying from cancer in community hospitals or a hospice: closest lay caregivers' perceptions. $\mathrm{Br} J$ Gen Pract 1998; 48: 1317-1321.

43 Spruyt, O. Community-based palliative care for Bangladeshi patients in east London. Accounts of bereaved caregivers. Palliat Med 1999; 13: 119-129.

44 Terry, W, Olson, L, Wilss, L, Boulton-Lewis, G. Experience of dying: concerns of dying patients and of carers. Intern Med J 2006; 36: 338-346.

45 Waldrop, D, Kramer, B, Skretny, JA, Milch, RA, Finn, W. Final transitions: family caregiving at the end of life. J Palliat Med 2005; 8: 623-638. 
46 Ward, SE, Berry, PE, Misiewicz, H. Concerns about analgesics among patients and family caregivers in a hospice setting. Res Nurs Health 1996; 19: 205-211.

47 Grande, GE, Todd, CJ. Why are trials in palliative care so difficult? Palliat Med 2000; 14: 69-74.

48 Higginson, IJ. It would be NICE to have more evidence? Palliat Med 2004; 18: 85-86.
49 Mays, N, Pope, C. Qualitative research in health care: assessing quality in qualitative research. $B M J 2000 ; \mathbf{3 2 0}$ : $50-52$.

50 Faull, C. The context and principles of palliative care. In Faull, C, Carter, Y, Daniels, G, The Handbook of Palliative Care. Oxford: Blackwell, 2005: 1-20.

51 Murray, SA, Kendall, M, Boyd, K, Sheikh, A. Illness trajectories in palliative care. BMJ 2005; 330: 1007-1011. 